\title{
Getting SLAPP Happy: Why the U.S. District Court for the District of Kansas Should Adopt the Ninth Circuit's Approach When Applying the Kansas Anti-SLAPP Law
}

\author{
Sydney Buckley*
}

I. INTRODUCTION

Bigfoot on the Strip - a Branson, Missouri, Sasquatch-themed amusement park-left a Kansas farmer and his daughter less than impressed in 2018. ${ }^{1}$ Upon returning home, Mr. Randy Winchester posted the following three-star review on TripAdvisor:

We did the Bigfoot Safari tour as part of a large group. The $\$ 10$ price tag is about right for what we got. Basically a tour through some pretty rugged country on some pretty narrow roads. They promote the fact they have the largest herd of Highland cows in the Midwest. You spend about 5-10 minutes feeding them range cubes at the beginning of the tour, and see maybe 10 of the cows. Then its [sic] off into the hills you go with a guide telling some pretty fanciful tales along the way. All in all a decent experience but had we paid more than the \$10 I would have been disappointed. $^{2}$

After posting this review, Mr. Winchester and his daughter received numerous phone calls and emails from Bigfoot on the Strip complaining about Mr. Winchester's criticism. ${ }^{3}$ One of these messages advised Mr. Winchester's daughter that the owner would bring a lawsuit for the review. ${ }^{4}$ After receiving these messages, Mr. Winchester lowered his three-star review to one star. ${ }^{5}$ Bigfoot on the Strip subsequently filed a

\footnotetext{
* J.D. Candidate, 2021, University of Kansas School of Law; B.A., 2018, Political Science, Fairfield University. I would like to thank the Kansas Law Review editors for their rigorous edits and suggestions. I would also like to give a special thank you to my friends and family for their input and continued support.

1. Bigfoot on the Strip, LLC v. Winchester, No. 18-3155-CV-S-BP, 2019 WL 4144320, at *24 (W.D. Mo. Aug. 30, 2019).

2. Id. at $* 2$.

3. Id. at *3.

4. Id.

5. Id.
} 
defamation lawsuit against Mr. Winchester and his daughter. ${ }^{6}$

Bigfoot on the Strip's lawsuit against Mr. Winchester is the prototypical strategic lawsuit against public participation (SLAPP). ${ }^{7}$ SLAPPs are (1) "based on the exercise of certain First Amendment petitioning rights" and (2) "unlikely to succeed on the merits." SLAPPs, as described by the Ninth Circuit, are lawsuits "defined by a particular strategy: obtaining an economic advantage over a defendant, and not necessarily the vindication of a cognizable legal right." In response to the rising use of SLAPP suits, many states have enacted anti-SLAPP laws to "root out and end frivolous cases - those brought only to harass or punish one's critics - before the costs of litigation escalate and prevent a defendant from mounting a defense." 10 Many anti-SLAPP statutes accomplish this by (1) giving defendants the ability to file motions to dismiss or strike early in the litigation; (2) requiring expedited hearings for these motions and imposing a discovery stay until the motions are heard; (3) requiring the plaintiff to show the case has a substantial probability of success on the merits; and (4) imposing sanctions awarding attorney's fees and costs when the plaintiff fails to meet its burden. ${ }^{11}$ Approximately thirty states have enacted anti-SLAPP statutes that provide for some form of an expedited motion to dismiss. ${ }^{12}$ Because anti-SLAPP laws advance their substantive policy goals by imposing procedural requirements that may conflict with the Federal Rules, federal courts have struggled to determine whether anti-SLAPP laws apply in federal diversity cases, where federal courts must apply state substantive law and federal procedural law. ${ }^{13}$ A quick review of Federal Rules of Civil Procedure 8, 12, and 56 helps focus the Erie problem that anti-SLAPP laws pose.

Rule 8 requires that a complaint contain "a short and plain statement

6. $I d$.

7. Professor George W. Pring coined the term "SLAPP." See George W. Pring, SLAPPs: Strategic Lawsuits Against Public Participation, 7 PACE ENVTL. L. REV. 3, 3-4 (1989).

8. Kathryn W. Tate, California's Anti-SLAPP Legislation: A Summary of and Commentary on Its Operation and Scope, 33 LOY. L.A. L. REV. 801, 803 (2000) (quoting Thomas A. Waldman, Comment, SLAPP Suits: Weaknesses in First Amendment Law and in the Courts' Responses to Frivolous Litigation, 39 UCLA L. REV. 979, 1044 (1992)).

9. Breazeale v. Victim Servs., Inc., 878 F.3d 759, 764 (9th Cir. 2017).

10. Memorandum from Lane Shetterly, Chair, Robert T. Sherwin, Reporter, \& Pub. Participation Prot. Act Drafting Comm. to the Nat'l Conference of Comm'rs on Unif. State Laws 3 (June 3, 2019), https://www.uniformlaws.org/HigherLogic/System/DownloadDocumentFile.ashx?DocumentFileKe $\mathrm{y}=341 \mathrm{c} 4466-1 \mathrm{f33}-\mathrm{c} 770-7 \mathrm{~d} 01-012$ eeaa47df0\&forceDialog $=0 \quad$ [https://perma.cc/7LCX-WNB9]

[hereinafter Memorandum from Shetterly].

11. Id.

12. State Anti-SLAPP Laws, PUB. PARTiCiPATION ProjeCt, https://anti-slapp.org/your-states -free-speech-protection [https://perma.cc/V7FD-ZER3] (last visited Apr. 7, 2020) [hereinafter Project] (listing states that have enacted anti-SLAPP laws and rating them based on quality).

13. See infra Section II.C. 
of the claim showing that the pleader is entitled to relief."14 The Supreme Court has established that Rule 8 requires complaints to "contain sufficient factual matter, accepted as true, to "state a claim to relief that is plausible on its face." "'15 If a complaint fails to meet this standard, the district court may grant a motion to dismiss under Rule 12(b)(6) for "failure to state a claim upon which relief can be granted."16 Finally, Rule 56 governs motions for summary judgment. ${ }^{17}$ Rule 56 allows summary judgment when "there is no genuine dispute as to any material fact and the movant is entitled to judgment as a matter of law," 18 and is therefore "appropriate only when the plaintiff has been able to come up with no evidence that would allow a reasonable jury to find in her favor." 19

Courts often struggle when considering whether the state anti-SLAPP statutes can coexist with the pleading and pretrial judgment standards laid out in Federal Rules 8, 12, and 56. The federal appellate courts are split as to whether anti-SLAPP statutes are procedural, and thus conflict with the Federal Rules, or whether they are substantive, and therefore can work together to dismiss SLAPPs brought in federal court at an early stage. ${ }^{20}$ The sole case from the U.S. District Court for the District of Kansas addressing the applicability of Kansas's anti-SLAPP statute in federal court $^{21}$ lacks the depth of the well-developed Ninth Circuit case law. ${ }^{22}$ As the U.S. District Court for the District of Kansas continues to develop its approach on this issue, it should follow the Ninth Circuit's recent efforts to circumscribe select provisions of anti-SLAPP statutes in federal diversity actions, while preserving the substantive provisions, because this approach best aligns with the purposes of the Erie doctrine.

Part II of this Comment provides a comprehensive background of the development of anti-SLAPP legislation, an introduction to the Kansas

\footnotetext{
14. FED. R. CIV. P. 8(a)(2).

15. Ashcroft v. Iqbal, 556 U.S. 662, 678 (2009) (quoting Bell Atl. Corp. v. Twombly, 550 U.S. $544,570(2007))$.

16. FED. R. CIV. P. 12(b)(6).

17. See FED. R. CIV. P. 56.

18. FED. R. CIV. P. 56(a).

19. Jonah B. Gelbah, Material Facts in the Debate Over Twombly and Iqbal, 68 STAN. L. ReV. $369,381-82,382 \mathrm{n} .41$ (2016) ("Note that 'no evidence that would allow a reasonable jury to find in her favor' is not the same thing as no evidence at all. It is not sufficient for a plaintiff to come up with a mere 'scintilla' of evidence, because courts impose a burden of production on parties that requires some minimal level of evidence that is more than simply a shred." (quoting Anderson v. Liberty Lobby, Inc., 477 U.S. 242, 252 (1986))).

20. See infra Section II.C.

21. Caranchini v. Peck, 355 F. Supp. 3d 1052 (D. Kan. 2018).

22. See United States ex rel. Newsham v. Lockheed Missiles \& Space Co., 190 F.3d 963, 97073 (9th Cir. 1999); Metabolife Int'1, Inc. v. Wornick, 264 F.3d 832, 837-40 (9th Cir. 2001); Makaeff v. Trump Univ., LLC, 715 F.3d 254, 260-65 (9th Cir. 2013); Planned Parenthood Fed'n of Am., Inc. v. Ctr. for Med. Progress, 890 F.3d 828, 832-35 (9th Cir. 2018), cert. denied, 139 S. Ct. 1446 (2019).
} 
anti-SLAPP statute, an overview of the current circuit split, a history of the Ninth Circuit's case law, and an introduction to the sole case addressing the applicability of Kansas's anti-SLAPP statute in federal diversity actions. Part III analyzes how the U.S. District Court for the District of Kansas - and ultimately the Tenth Circuit - might adopt the reasoning from Ninth Circuit case law to protect the integrity of the antiSLAPP provisions while not running afoul of the Erie doctrine. Part IV concludes by confronting common objections and proffering how the use of the Kansas anti-SLAPP statute may affect future litigation in the U.S. District Court for the District of Kansas.

\section{BACKGROUND}

This Part outlines the origins of anti-SLAPP legislation and introduces the language of the Kansas anti-SLAPP statute. It then explains the root of the current controversy by examining the Erie progeny and evaluates why these decisions have led to a circuit split regarding the applicability of anti-SLAPP statutes in federal courts. Finally, this Part looks at the Ninth Circuit's body of case law addressing this issue, and the sole case addressing the applicability of the Kansas anti-SLAPP statute in federal diversity actions.

\section{A. Origins of Anti-SLAPP Legislation}

SLAPPs are generally meritless lawsuits that are brought against individuals for exercising certain First Amendment petitioning rights in an attempt to chill free speech. ${ }^{23}$ Anti-SLAPP statutes seek to combat these meritless lawsuits by establishing "a special motion to dismiss procedure, with little or no discovery, that can quickly dispose" of such lawsuits. ${ }^{24}$ These statutes are of great benefit to defendants because eighty to ninety percent of SLAPP plaintiffs do not prevail at trial. ${ }^{25}$ Since the early $1990 \mathrm{~s}$, approximately thirty states have enacted anti-SLAPP legislation ${ }^{26}$ in an effort to protect their citizens from large private interests that seek to

23. Tate, supra note 8, at 802-03.

24. Cliff Zatz et al., What's Next for Federal Anti-SLAPP Legislation, LAw360 (Apr. 19, 2017, 12:21 PM), https:/www.law360.com/articles/914702/what-s-next-for-federal-anti-slapp-legislation; see also Jay Adkisson, Anti-SLAPP Statutory Oddities, FoRBES (Oct. 31, 2017, 8:01 PM), https://www.forbes.com/sites/jayadkisson/2017/10/31/anti-slapp-statutory-oddities/\#7b14777f2037 [https://perma.cc/G34Y-RFEQ] ("Litigators should think of an Anti-SLAPP motion as something akin to a "motion to dismiss on steroids."').

25. Tate, supra note 8, at 804 (citing John C. Barker, Common-Law and Statutory Solutions to the Problem of SLAPPs, 26 LOY. L.A. L. REV. 395, 406 (1993)).

26. Project, supra note 12. 
"deter common citizens from exercising their political or legal rights or to punish them for doing so." 27

SLAPPs can be brought by or against any litigant, but they tend to share common trends. They are usually filed by government officials or businesses against individuals who openly oppose them on issues of public interest. ${ }^{28}$ These individuals are usually people with fewer resources who lack the time and money to defend a lawsuit. ${ }^{29}$ SLAPPs commonly result from actions such as submitting letters to the editor, distributing flyers or petitions, engaging in demonstrations, speaking at public hearings, and filing lawsuits. ${ }^{30}$ Although the types of claims brought in SLAPPs can be widespread, they too are marked by many shared characteristics. They generally come in the form of ordinary civil claims, with defamation being one of the most common. ${ }^{31}$ SLAPPs "are most often provoked by: [p]articipation at public hearings (47\%); [f]iling public interest litigation (20\%); [r]eporting violations of laws or regulations (18\%); [1] odging formal government complaints $(8 \%)$; or [p] eaceful protests and legal boycotts (3\%)." ${ }^{32}$ The increase in the use of SLAPPs prompted many states legislatures to enact statutes allowing defendants to bring a special motion to dismiss at an early stage in the litigation. ${ }^{33}$

Generally, anti-SLAPP statutes share two key features: (1) "they provide an expedited procedure to short-circuit SLAPPs, conserving all parties' time and resources," and (2) they award defendants who win the motion to dismiss attorney's fees and costs. ${ }^{34}$ Despite these similarities, however, state legislatures often adopt varying approaches, and state antiSLAPP statutes are not a "one-size-fits-all model." ${ }^{35}$ Delaware's antiSLAPP statute, for example, only covers suits arising from government permits and various licensing issues, ${ }^{36}$ while Pennsylvania's anti-SLAPP

27. GOLO, LLC v. Higher Health Network, LLC, No. 3:18-cv-2434, 2019 WL 446251, at *5 (S.D. Cal. Feb. 5, 2019) (quoting Wilcox v. Superior Court, 33 Cal. Rptr. 2d 446, 450 (1994)).

28. What Is a SLAPP Suit?, ACLU OHIO, https://www.acluohio.org/slapped/what-is-a-slapp-suit [https://perma.cc/XC9N-G4BV] (last visited Apr. 7, 2020).

29. Id.

30. Id.

31. Id.

32. Id.

33. Memorandum from Shetterly, supra note 10, at 2-3.

34. Sean D. Lee, "I Hate My Doctor": Reputation, Defamation, and Physician-Review Websites, 23 HeAlth MATRIX 573, 591 (2013); see also Project, supra note 12. Most states with anti-SLAPP statutes provide for the recovery of attorney's fees. Project, supra note 12. Delaware, Maine, Maryland, Nebraska, New York, Oklahoma, Utah, and Virginia are the few states that do not. $I d$.

35. Zatz et al., supra note 24 (citations omitted).

36. Del. Code ANN. tit. 10, § 8136(a)(4) (West, Westlaw through ch. 239 of 150th Gen. Assemb.). 
statute only covers suits that arise from environmental issues. ${ }^{37}$ California has one of the broadest anti-SLAPP statutes - it applies to any case resulting from an individual's exercise of their right to petition and free speech. ${ }^{38}$ Other state statutes include some colorful variations. For example, Arizona's statute encourages successful SLAPP defendants to seek additional sanctions ${ }^{39}$ which likely include sanctions against the plaintiff as well as the attorney who filed the SLAPP. ${ }^{40}$ Hawaii's statute gives the court explicit authority to impose sanctions on the plaintiff, its attorney, and even the law firms. ${ }^{41}$ Despite the many variations among state anti-SLAPP statutes, they are all designed to "protect[] citizens from [the] David and Goliath power difference." 42

\section{B. The Kansas Anti-SLAPP Statute}

In 2016, Kansas enacted its anti-SLAPP statute, the Kansas Public Speech Protection Act. ${ }^{43}$ The statute's provisions are representative of many other state anti-SLAPP statutes. ${ }^{44}$ The Act's stated purpose "is to encourage and safeguard the constitutional rights of a person to petition, and speak freely and associate freely, in connection with a public issue or issue of public interest ... while, at the same time, protecting the rights of a person to file meritorious lawsuits for demonstrable injury." 45 The Kansas statute, like many of its kind, protects speech relating to a "public issue or issue of public interest." 46 The statute defines this as anything related to "[h]ealth or safety," "environmental, economic or community well-being," "the government," "a public official or public figure," or "a good, product or service in the marketplace." $" 47$

Procedurally, once a SLAPP is brought, the defendant can move to dismiss because it implicates the exercise of their right to assemble, petition, or speak freely. ${ }^{48}$ The Kansas statute provides a burden-shifting test: while the defendant bears the initial burden of showing the claim

\footnotetext{
37. 27 Pa. Cons. Stat. ANN. $\S \S 7707,8301-8305$ (West, Westlaw through 2020 Reg. Sess.).

38. CAL. CIV. PRo. Code $\S 425.16$ (b)(1) (Deering 2019).

39. ARiZ. Rev. Stat. AnN. § 12-752(B) (West, Westlaw through 2d Reg. Sess.).

40. Adkisson, supra note 24.

41. HaW. Rev. Stat. ANN. § 634F-2(8)(C) (West, Westlaw through end of 2019 Reg. Sess.).

42. Lori A. Roberts, Brawling with the Consumer Review Site Bully, 84 U. CIN. L. REV. 633, 658 (2016) (quoting Stuborn Ltd. P'ship v. Bernstein, 245 F. Supp. 2d 312, 314 (D. Mass. 2003)).

43. See Kan. Stat. AnN. § 60-5320 (West 2016 \& Supp. 2019).

44. See supra Section II.A.

45. KAN. STAT. ANN. $\S 60-5320(\mathrm{~b})$.

46. Id. $\S 60-5320(\mathrm{c})(4)$.

47. Id. $\S 60-5320(\mathrm{c})(7)(\mathrm{A})-(\mathrm{E})$.

48. Id. $\S 60-5320(\mathrm{~d})$.
} 
"concerns a party's exercise of the right of free speech, right to petition or right of association," once shown, the burden shifts to the plaintiff to demonstrate "a likelihood of prevailing on the claim by presenting substantial competent evidence to support a prima facie case."49 If the defendant prevails and the court strikes the claim, the defendant is entitled to recover litigation costs and attorney's fees from the plaintiff. $^{50}$

\section{The Controversy}

There is no federal anti-SLAPP statute. Because state anti-SLAPP statutes have both procedural and substantive elements, federal courts disagree as to whether state anti-SLAPP statutes apply in federal diversity actions, where federal courts must apply state substantive law and federal procedural law. ${ }^{51}$ Those who oppose application of anti-SLAPP statutes in federal court generally view anti-SLAPP statutes as purely procedural instruments. ${ }^{52}$ Anti-SLAPP laws, however, employ procedural means to achieve substantive results. ${ }^{53}$ From this perspective, "it is impossible to characterize them as purely procedural," and state anti-SLAPP statutes should therefore apply in federal court. ${ }^{54}$ This Section provides an overview of the Erie doctrine, explains why the Erie progeny presents a roadblock in applying state anti-SLAPP statutes in federal court, and discusses the deepening circuit split in the wake of more recent Erie cases.

\footnotetext{
49. Id.

50. Id. $\S 60-5320(\mathrm{~g})$.

51. Compare Abbas v. Foreign Policy Grp., LLC, 783 F.3d 1328, 1337 (D.C. Cir. 2015) (holding that federal courts "exercising diversity jurisdiction ... must apply Federal Rules 12 and 56 instead of the D.C. Anti-SLAPP Act's special motion to dismiss provision" because the Federal Rules "answer the same question" as the D.C. Anti-SLAPP statute), and Carbone v. Cable News Network, Inc., 910 F.3d 1345, 1356-57 (11th Cir. 2018) (determining that the motion-to-strike provision in Georgia's anti-SLAPP statute directly conflicts with the Federal Rules), with United States ex rel. Newsham v. Lockheed Missiles \& Space Co., 190 F.3d 963, 973 (9th Cir. 1999) (finding that California's antiSLAPP statute applies in federal diversity actions because there is no "direct collision" between the statute and the Federal Rules).

52. Roni A. Elias, Applying Anti-SLAPP Laws in Diversity Cases: How to Protect the Substantive Public Interest in State Procedural Rules, 41 T. MARSHALl L. REV. 215, 216 (2016) ("The argument against applying state anti-SLAPP statutes in federal diversity cases is persuasive if those statutes are understood as entirely, or even predominantly, procedural. The courts challenging the federal application of state anti-SLAPP statutes have this understanding, interpreting those statutes as giving private litigants a collection of special procedural instruments for defending or asserting their private rights.").

53. Id. (arguing that anti-SLAPP laws should be "understood as using procedural means to accomplish a substantive end").

54. Id.
} 


\section{The Erie Doctrine}

The Erie doctrine guides a federal court's decision on whether to apply state law in a federal diversity action. ${ }^{55}$ Erie requires that "federal courts sitting in diversity apply state substantive law and federal procedural law." 56 Characterizing a law as either "substantive" or "procedural" is often no easy task, ${ }^{57}$ however, and requires working through the complexities and uncertainties of the contemporary Erie doctrine. ${ }^{58}$ The 1938 Erie Railroad Co. v. Tompkins decision spurred a long line of subsequent cases attempting to navigate the complexities left open in the opinion. ${ }^{59}$ Erie and its progeny have been the subject of scholarly debate for decades, ${ }^{60}$ and this Comment does not attempt to examine its intricate nuances. As Professor John Corr acknowledged, "[t]he difficulties of mastering the application of Erie are well known to those who study it" and "[t]he superficial simplicity of a rule sometimes requiring federal courts to apply state law becomes, on closer examination, a swamp of confusion that can trap everyone from legal neophytes to the most astute of federal judges." ${ }^{\prime 61}$ An abbreviated discussion of the Supreme Court's landmark decisions on this question is nonetheless warranted to understand the difficulty of determining whether state anti-SLAPP statutes are procedural or substantive for Erie purposes.

After Erie, the Court in Guaranty Trust Co. v. York continued to command that federal courts respect state law. ${ }^{62}$ The Guaranty Trust

55. See Erie R.R. Co. v. Tompkins, 304 U.S. 64 (1938); see also Colin Quinlan, Note, Erie and the First Amendment: State Anti-SLAPP Laws in Federal Court After Shady Grove, 114 ColuM. L. REV. 367, 377-79 (2014) ("When federal courts adjudicate claims arising under state law, they look to the Erie doctrine to determine which state laws they must apply.").

56. Gasperini v. Ctr. for Humanities, Inc., 518 U.S. 415, 427 (1996).

57. Id. ("Classification of a law as 'substantive' or 'procedural' for Erie purposes is sometimes a challenging endeavor.").

58. Adam N. Steinman, What Is the Erie Doctrine? (And What Does It Mean for the Contemporary Politics of Judicial Federalism?), 84 Notre DAME L. REV. 245, 251 (2008); see also Richard D. Freer, Erie's Mid-Life Crisis, 63 Tul. L. REv. 1087, 1101-02 (1989) (“Erie ... gave birth ... to a jurisprudence of labels that has since haunted the federal courts. ... The ensuing fifty years ... have demonstrated the difficulty of distinguishing substance from procedure in less clearcut cases.").

59. See, e.g., Guar. Tr. Co. v. York, 326 U.S. 99 (1945); Byrd v. Blue Ridge Rural Elec. Coop., Inc., 356 U.S. 525 (1958); Hanna v. Plumer, 380 U.S. 460 (1965); Gasperini v. Ctr. for Humanities, Inc., 518 U.S. 415, 426 (1996).

60. See Steinman, supra note 58, at 247 ("Erie has achieved a mythic status, and it has been a constant subject of scholarly debate and analysis.").

61. John B. Corr, Thoughts on the Vitality of Erie, 41 AM. U. L. REV. 1087, 1089 (1992).

62. 326 U.S. 99 (1945); see Daniel R. Gordon, Revisiting Erie, Guaranty Trust, and Gasperini: The Role of Jewish Social History in Fashioning Modern American Federalism, 26 SEATTLE U. L. REV. 213, 226 (2002) ("In Erie and Guaranty Trust, the Justices applied state law and emphasized the importance of state government, legislatures, and courts."). 
Court was tasked with resolving whether a statute of limitation was substantive or procedural. ${ }^{63}$ The Court determined that Erie sought to ensure that "the outcome of the litigation in the federal court should be substantially the same ... as it would be if tried in a State court." the Court found that failing to apply a substantive state law in a federal diversity action would substantially affect the case outcome, but if a state law were purely procedural, it would only regulate how a right is enforced, and not materially affect the outcome of the litigation. ${ }^{65}$ The Court found that a statute of limitation is outcome-determinative, and therefore substantive for Erie purposes, because it can place a complete bar on recovery. ${ }^{66}$

Although the Court initially seemed inclined to favor application of state law, however, it subsequently changed course in its 1958 Byrd v. Blue Ridge Rural Electric Cooperative, Inc. decision. ${ }^{67}$ The Byrd Court assessed whether a federal court sitting in diversity must apply South Carolina law requiring that a judge, rather than a jury, determine if a plaintiff is a statutory employee, and thus limited to recovery under South Carolina's workers' compensation law. ${ }^{68}$ Justice Brennan, writing for the Court, held that federal courts must follow the federal practice of jury determination. ${ }^{69}$ In resolving the issue, the Byrd Court proffered a balancing test for traditionally "procedural" areas that defer to the state law if it is "bound-up with [state-based] rights and obligations." situations where the state rule is not bound-up with state-based rights and obligations, the federal rule is preferred. ${ }^{71}$ The Byrd balancing test proved difficult to apply in practice, and perhaps it was in part this difficulty that caused the Supreme Court to make a radical shift in Hanna v. Plumer. ${ }^{72}$

The question before the Court in Hanna was whether Federal Rule 4

63. Guar. Tr. Co., 326 U.S. at 107.

64. Id. at 109 .

65. Id. at $110-11$.

66. Id. at $111-12$.

67. 356 U.S. 525 (1958).

68. Id. at $533-34$.

69. Id. at 538 .

70. Id. at $538-39$.

71. Id. at 537 .

72. Michael A. Berch \& Rebecca White Berch, An Essay Regarding Gasperini v. Center for Humanities, Inc. and the Demise of the Uniform Application of the Federal Rules of Civil Procedure, 69 Miss. L.J. 715, 722 (1999); see also J. Benjamin King, Note, Clarification and Disruption: The Effect of Gasperini v. Center for Humanities, Inc. on the Erie Doctrine, 83 CoRnELL L. REV. 161, 170 (1997) ("Byrd complicated the analysis because "it provides ambiguous guidance as to when - aside from the precise circumstances present in the Byrd case-federal rules will prevail in the face of contrary state rules." (quoting 19 Charles Alan Wright ET AL., Federal Practice AND PROCEDURE $§ 4504$ (2d ed. 1996)). 
or a contrary state rule governed service of process in a state personal injury action. ${ }^{73}$ The Court explained that "when a situation is covered by one of the Federal Rules, the question facing the court is a far cry from the typical, relatively unguided Erie choice." 74 Where the Federal Rules are at issue, the Court announced, the Rules Enabling Act (REA) ${ }^{75}$ is the focus, and a federal court may "refuse to [apply a Federal Rule] only if the Advisory Committee, this Court, and Congress erred in their prima facie judgment that the Rule" does not violate the REA or constitutional restrictions. ${ }^{76}$ The Court thus held that Federal Rule 4, not the conflicting state rule, governed the sufficiency of service. ${ }^{77}$ The Hanna Court, as one author put it, "enshrined a bifurcated approach to Erie questions." Professor Richard Freer described the two separate inquiries at work in Hanna:

First, if Congress has directed the federal courts to apply a particular rule, and if that command is constitutional, the federal law applies. There is no concern with outcome determination, balancing, or any other Erie test because the Rules of Decision Act does not apply. Second, if there is no congressional direction to apply federal law, such as the Federal Rules, the court must assess the case under the Rules of Decision Act. The tribunal is then left with "the typical, relatively unguided Erie choice.",79

The Hanna Court seemed to retreat from Byrd's balancing test and preferred applying the federal law in situations not covered by a rule adopted pursuant to the REA. ${ }^{80}$ And, Hanna modified Guaranty Trust's outcome-determinative test by stressing Erie's twin aims and providing that when considering whether the competing state and federal rules will result in a different outcome, courts must make this determination from the point of view of a plaintiff choosing where to file their case. ${ }^{81}$

73. Hanna v. Plumer, 380 U.S. 460, 461 (1965).

74. Id. at 471 .

75. The REA gives the Supreme Court authority to create "general rules of practice and procedure" in civil suits, but states that "[s]uch rules shall not abridge, enlarge or modify any substantive right.” 28 U.S.C. $§ 2072$ (2018).

76. Freer, supra note 58, at 1104 (quoting Hanna, 380 U.S. at 471).

77. Hanna, 380 U.S. at $463-64$.

78. Steinman, supra note 58, at 260.

79. Freer, supra note 58, at 1104-05 (quoting Hanna, 380 U.S. at 471); see also 28 U.S.C. § 1652 (2018) (mandating that substantive state law be applied in state cases, unless the United States Constitution, Treaties of the United States, or Congress says otherwise).

80. Berch \& Berch, supra note 72, at 723-24. The Court expressed this preference for application of the federal rules "unless it would encourage forum shopping or foster the inequitable administration of the laws," though "[1]ater cases attempted to hew to this line of reasoning." Id.

81. See Hanna, 380 U.S. at 469 ("Though choice of the federal or state rule will at this point have a marked effect upon the outcome of the litigation, the difference between the two rules would be of scant, if any, relevance to the choice of a forum."). 
Several decades later, the Court decided Gasperini v. Center for Humanities, Inc., which involved the Seventh Amendment right to trial by jury and a New York law governing appellate review of jury verdicts. ${ }^{82}$ In Gasperini, a journalist brought suit in federal court based on diversity jurisdiction seeking damages for the defendant's loss of photographic transparencies of pictures he took in Central America. ${ }^{83}$ The jury awarded the plaintiff $\$ 450,000$ in damages. ${ }^{84}$ The defendant moved for a new trial under Rule 59, arguing that the $\$ 450,000$ verdict was excessive. ${ }^{85}$ The trial court denied the motion, and on appeal, the Second Circuit vacated the jury's verdict and ordered a new trial. ${ }^{86}$ The Supreme Court granted certiorari because the case posed a difficult Erie question about what standard a federal district court must use to "measure the alleged excessiveness of a jury's verdict" in a state law action. ${ }^{87}$

While Federal Rule 59(a)(1) permits motions for a new trial "for any of the reasons for which new trials have heretofore been granted in actions at law in the courts of the United States," Rule 59 does not provide any standard to examine an excessive verdict. ${ }^{88}$ Federal courts in New York traditionally employ the "shock the conscience" standard to decide whether to order a new trial. ${ }^{89}$ The conflict in Gasperini arose from the tension between the federal "shock the conscience" standard and a New York tort reform law that required New York state courts to inquire whether the verdict "deviates materially from what would be reasonable compensation." 90

One of the Erie issues that the Gasperini Court confronted was whether federal judges faced with a new trial motion should apply the state or federal sufficiency of the evidence standard when determining if a jury's damages award was excessive. ${ }^{91}$ The defendant contended that the New York law was substantive, and plaintiff argued that it was procedural, and that if it were to apply, it would violate both the jury's right to establish damages and the Seventh Amendment's reexamination clause. ${ }^{92}$ Justice Ginsburg, writing for the Court, found that the New York law was both

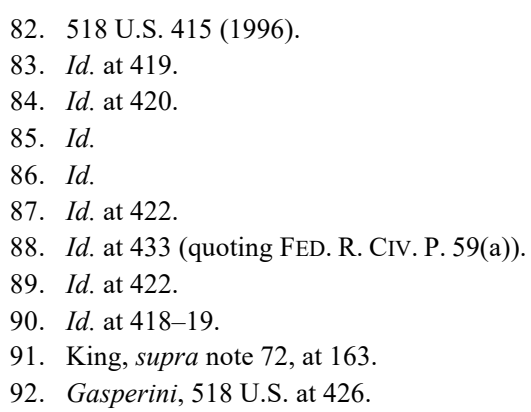


substantive and procedural for Erie purposes. ${ }^{93}$ The Court held that to serve the "twin aims" of Erie recognized in Hanna - preventing forum shopping and inequitable administration of the laws - the more "rigorous" state standard must apply. ${ }^{94}$

The Court's accommodation of the state standard marked a shift towards giving heightened deference to state law by allowing state law to define the substance of a Federal Rule of Civil Procedure. ${ }^{95}$ Gasperini's holding was significant to the Erie doctrine because it added that even when a Federal Rule may be broad enough to control, the Federal Rule's application may still, at least implicitly, require application of the underlying state laws. ${ }^{96}$ And, Gasperini "confirmed Byrd's place in the Erie analysis because the Court explicitly engaged in a Byrd balancing test" by examining if there were any countervailing federal interests outweighing the state interest in applying the New York standard. ${ }^{97}$ Thus, Gasperini stands to allow state procedure to "displace federal procedure within the scope of a Federal Rule." 98 The Court, in dicta, also noted the importance of interpreting Federal Rules "with sensitivity to important state interests and regulatory policies." 99

Armed with this understanding, the unique Erie issue posed by state anti-SLAPP laws becomes clear. ${ }^{100}$ The majority of anti-SLAPP statutes "rely on procedural mechanisms to protect substantive rights."101 This makes it difficult for federal courts sitting in diversity, because under the Erie doctrine, federal courts must apply state substantive law, but all civil proceedings in federal court require application of the Federal Rules. ${ }^{102}$ Anti-SLAPP laws tend to raise questions about Federal Rule 12(b)(6)

93. Id.

94. Id. at $428-30$.

95. See King, supra note 72, at 183.

96. Benjamin Grossberg, Comment, Uniformity, Federalism, and Tort Reform: The Erie Implications of Medical Malpractice Certificate of Merit Statutes, 159 U. PA. L. REV. 217, 239 (2010).

97. King, supra note 72 , at $183-84$.

98. Id. at 183 .

99. Gasperini, 518 U.S. at 427 n.7. After this analysis, the Court also considered whether the Seventh Amendment's limit of appellate review precluded the application of state law.

100. See Caranchini v. Peck, 355 F. Supp. 3d 1052, 1058 (D. Kan. 2018) ("Courts deciding whether these anti-SLAPP statutes apply in federal court agree that the issue falls into the 'special category concerning the relationship between the Federal Rules of Civil Procedure and a state statute that governs both procedures and substance in the state courts,' which is not the 'classic Erie question."” (quoting Godin v. Schencks, 629 F.3d 79, 86 (1st Cir. 2010))).

101. Quinlan, supra note 55, at 368.

102. See, e.g., Gasperini, 518 U.S. at 428 ("Under the Erie doctrine, federal courts sitting in diversity apply state substantive law and federal procedural law."); Shady Grove Orthopedic Assocs., P.A. v. Allstate Ins. Co., 559 U.S. 393, 398 (2010) (plurality opinion) ("The framework for our decision is familiar. We must first determine whether [the Federal Rule] answers the question in dispute. If it does, it governs ....”). 
motions to dismiss and Federal Rule 56 summary judgment motions because they appear to conflict with state anti-SLAPP statutes that "set their own threshold a claimant must meet to proceed with their case." 103

This apparent tension between the Federal Rules and state anti-SLAPP statutes further grew after the Supreme Court decided Shady Grove Orthopedic Associates, P.A. v. Allstate Insurance Co. in 2010. ${ }^{104}$ In Shady Grove, a New York statute required the defendant, Allstate, to pay interest on Shady Grove's insurance claim. ${ }^{105}$ When Allstate refused to pay, the plaintiff filed a diversity action in the Eastern District of New York, and later filed a Rule 23 motion to certify a class action. ${ }^{106}$ But, a New York law prohibited class actions from being formed for the purpose of collecting this kind of statutory interest. ${ }^{107}$ A splintered Court discussed a number of potential routes for settling a conflict between the Federal Rule and the New York law. ${ }^{108}$ But five Justices "agreed that a state law could be 'procedural' and yet so important in defining the scope of substantive rights that the Federal Rules could not displace it." 109

Nevertheless, Shady Grove failed to provide a clear answer. The three opinions-Justice Scalia's plurality opinion, Justice Stevens's concurrence, and Justice Ginsburg's dissent - have caused lower federal courts to disagree about which parts of Shady Grove control. ${ }^{110}$ Justice Scalia argued that when a Federal Rule "regulates procedure," it is "valid in all jurisdictions, with respect to all claims, regardless of its incidental

\footnotetext{
103. Aaron Smith, Note, SLAPP Fight, 68 ALA. L. REV. 303, 311 (2016).

104. 559 U.S. 393 (2010) (plurality opinion).

105. Id. at 397.

106. Id.

107. Id.

108. Id. at 416 (finding Federal Rule 23 directly applicable because "[t]he short of the matter is that a Federal Rule governing procedure is valid whether or not it alters the outcome of the case in a way that induces forum shopping"); id. at 416-17 (Stevens, J., concurring) ("I agree with Justice Scalia that Federal Rule of Civil Procedure 23 must apply in this case ... . But I also agree with Justice Ginsburg that there are some state procedural rules that federal courts must apply in diversity cases because they function as a part of the State's definition of substantive rights and remedies."); $i d$. at 447, 456 (Ginsburg, J., dissenting) (finding that narrowly construing Rule 23 allows for application of the state law, and asserting that "forum shopping will undoubtedly result if a plaintiff need only file in federal instead of state court to seek a massive monetary award explicitly barred by state law”).

109. Quinlan, supra note 55, at 368.

110. Compare 3M Co. v. Boulter, 842 F. Supp. 2d 85, 95 n.7 (D.D.C. 2012) (“Although some other courts may rely on Justice Stevens' concurrence in Shady Grove for determining the first question (i.e., whether the federal rules cover the dispute at issue or answer the same question as the state law), this Court believes that the analysis set forth in Part II-A of Shady Grove is the controlling test that district courts must apply."), with In re Wellbutrin XL Antitrust Litig., 756 F. Supp. 2d 670, 675 (E.D. Pa. 2010) (finding that Justice Stevens' Shady Grove analysis is binding because it forms the "narrowest grounds" in Shady Grove, and collecting cases where lower courts have concluded the same).
} 
effect upon state-created rights." ${ }^{111}$ Justice Stevens argued that a Federal Rule "cannot govern" a case where "the rule would displace a state law that is procedural in the ordinary use of the term but is so intertwined with a state right or remedy that it functions to define the scope of the statecreated right," and that "absent a governing federal rule, a federal court must engage in the traditional Rules of Decision Act inquiry, under the Erie line of cases." 112 In dissent, Justice Ginsburg wrote that had the Court first evaluated if the conflict was "really necessary," the Court would not have read the Federal Rule to collide with the state's legitimate interest, because Federal "Rule 23 describes a method of enforcing a claim for relief, while the state law defines the dimensions of the claim itself."113

Next, this Section discusses the well-developed circuit split and addresses how courts have used the Erie doctrine to either support or refuse application of state anti-SLAPP statutes in federal diversity actions.

\section{The Circuit Split}

The D.C., Seventh, Tenth, and Eleventh Circuits hold that certain antiSLAPP laws do not apply in federal court, ${ }^{114}$ whereas the First and Ninth Circuits find that certain state anti-SLAPP laws may apply in federal court. ${ }^{115}$ The Fifth Circuit has ruled both ways depending on the content of the state anti-SLAPP law before the court. ${ }^{116}$ These decisions, as demonstrated by the Fifth Circuit, are partly a result of the particular language of the state statute at issue. Many of the discrepancies, however, also result from the lack of guidance from Shady Grove. ${ }^{117}$ The clearest example of diverging outcomes resulting from the lack of clarity in Shady Grove is the First Circuit's Godin v. Schencks ${ }^{118}$ and the D.C. Circuit's

111. Shady Grove, 559 U.S. at 410.

112. Id. at 423-24 (Stevens, J., concurring).

113. Id. at 437, 447 (Ginsburg, J., dissenting).

114. Abbas v. Foreign Policy Grp., LLC, 783 F.3d 1328, 1332 (D.C. Cir. 2015); Intercon Sols., Inc. v. Basel Action Network, 791 F.3d 729, 732 (7th Cir. 2015); Los Lobos Renewable Power, LLC v. AmeriCulture, Inc., 885 F.3d 659, 673 (10th Cir. 2018); Carbone v. Cable News Network, Inc., 910 F.3d 1345, 1347 (11th Cir. 2018).

115. Godin v. Schencks, 629 F.3d 79, 91-92 (1st Cir. 2010); Planned Parenthood Fed'n of Am., Inc. v. Ctr. for Med. Progress, 890 F.3d 828, 835 (9th Cir. 2018), cert. denied, 139 S. Ct. 1446 (2019).

116. Klocke v. Watson, 936 F.3d 240, 245 (5th Cir. 2019) (declining to apply the Texas antiSLAPP statute because its "burden-shifting framework imposes additional requirements beyond those found in [Federal] Rules 12 and 56 and answers the same question as those rules"); Lozovyy v. Kurtz, 813 F.3d 576, 582-83 (5th Cir. 2015) (deciding to apply the Louisiana anti-SLAPP statute in federal court).

117. Katelyn E. Saner, Note, Getting SLAPP-ed in Federal Court: Applying State Anti-SLAPP Special Motions to Dismiss in Federal Court After Shady Grove, 63 DuKE L.J. 781, 801-02 (2013); Quinlan, supra note 55, at 368-69.

118. 629 F.3d 79 (1st Cir. 2010). 
Abbas v. Foreign Policy Group, $L L C^{119}$ opinions. Though the two courts were presented with the same legal question regarding a strikingly similar state law, the courts' interpretations of Shady Grove led to two diverging outcomes.

The special motion to dismiss provisions of the Maine and District of Columbia anti-SLAPP statutes were at issue in Godin ${ }^{120}$ and Abbas, ${ }^{121}$ respectfully. Both statutes are broad - they apply to statements made about any issues of public interest, safeguard an individual's right to petition, and prevent the heavy legal burdens that SLAPP suits place on defendants. ${ }^{122}$ Once a SLAPP defendant files the special motion, the court prioritizes the motion. ${ }^{123}$ An automatic stay freezes discovery unless the plaintiff can show good cause and that allowing limited discovery would not be unduly burdensome. ${ }^{124}$ Both statutes require the court to first determine whether the asserted claim is based on the defendant's petitioning rights. ${ }^{125}$ The Maine statute provides that the court will grant the motion unless the plaintiff can demonstrate that the defendant's exercise of its petitioning right "was devoid of any reasonable factual support or any arguable basis in law" and that the plaintiff was actually injured by the defendant's acts. ${ }^{126}$ The District of Columbia statute states that the court should grant the motion unless the plaintiff can demonstrate a likelihood of prevailing on the merits. ${ }^{127}$ Despite the similarities, the First Circuit and D.C. Circuit reached differing conclusions as to the applicability of the statutes. ${ }^{128}$

The First Circuit in Godin found that Rules 12 and 56 do not

119. 783 F.3d 1328 (D.C. Cir. 2015).

120. See 629 F.3d at $81-82$.

121. See 783 F.3d at 1332.

122. See D.C. Code Ann. § 16-5502 (West, Westlaw through Mar. 2019); Me. Rev. Stat. Ann. tit. 14, §556 (Westlaw through ch. 676 of 2019 2d Reg. Sess.).

123. The District of Columbia law requires the court to give the special motion priority over other cases. See D.C. CODE ANN. § 16-5502(d) ("The court shall hold an expedited hearing on the special motion to dismiss, and issue a ruling as soon as practicable after the hearing."). Unlike the District of Columbia law, the Maine law provides the court with discretion over this matter. See ME. REv. Stat. ANN. tit. 14, §556 ("The special motion may be advanced on the docket and receive priority over other cases when the court determines that the interests of justice so require.").

124. D.C. CODE ANN. § 16-5502(c); 14 ME. Rev. STAT. ANN. tit. 14, § 556.

125. D.C. Code ANN. § 16-5502(b); 14 Me. Rev. Stat. ANN. tit. 14, § 556.

126. ME. REV. STAT. ANN. tit. 14, § 556.

127. D.C. CODE ANN. § 16-5502(b). Note that the Kansas anti-SLAPP statute states that the court must grant the special motion unless the plaintiff can establish a "likelihood of prevailing on the claim by presenting substantial competent evidence to support a prima facie case." KAN. STAT. ANN. §605320(d) (West 2016 \& Supp. 2019).

128. See Godin v. Schnecks, 629 F.3d 79, 81 (1st Cir. 2010) (applying the Maine anti-SLAPP statute); Abbas v. Foreign Policy Grp., LLC, 783 F.3d 1328, 1332 (D.C. Cir. 2015) (recognizing that the court must follow the Federal Rules instead of the D.C. anti-SLAPP statute, but affirming on alternate grounds). 
"attempt[] to answer the same question" as Maine's anti-SLAPP statute. ${ }^{129}$ The court seemed to follow the reasoning in Justice Ginsburg's Shady Grove dissent instead of the approaches expressed by Justice Scalia or Justice Stevens. ${ }^{130}$ The First Circuit interpreted Rules 12 and 56 narrowly to avoid conflict with the Maine anti-SLAPP law, just as Justice Ginsburg narrowly read Rule 23 in Shady Grove. ${ }^{131}$ The court first assessed whether the state law and Federal Rules 12 and 56 can comfortably coexist, or whether the Federal Rules at issue were intended to "occupy the field." 132 A Federal Rule must be applied over a state law if evidence suggests that the Federal Rule was intended to "occupy the field." 133 Godin held that Rules 12 and 56 were not broad enough to cover the specific issue presented in Maine's anti-SLAPP statute. ${ }^{134}$ Unlike Rules 12 and 56, Maine's anti-SLAPP statute did not address "general federal procedures" that govern a wide category of cases, but rather "only addressed [] special procedures for state claims based on a defendant's petitioning activity." 135 Maine's statute was thus "not created [to] substitute" any of the Federal Rules. ${ }^{136}$ Rather, Maine "created a supplemental and substantive rule to provide added protections" to SLAPP defendants sued for exercising their constitutional right to participate in petitioning activities. ${ }^{137}$ The court also pointed out that the anti-SLAPP statute created a substantive burdenshifting provision, while Rules 12 and 56 are silent as to which party bears the burden of proof. ${ }^{138}$ These considerations led the First Circuit to find that Federal Rules 12 and 56 "can exist side by side" with the Maine antiSLAPP statute, "each controlling its own intended sphere of coverage without conflict." 139

129. Godin, 629 F.3d at 87-88 (alteration in original) (quoting Shady Grove Orthopedic Assocs., P.A. v. Allstate Ins. Co., 559 U.S. 393, 399 (2010) (plurality opinion)) ("Maine has not created a substitute to the Federal Rules, but instead created a supplemental and substantive rule to provide added protections, beyond those in Rules 12 and 56, to defendants who are named as parties because of constitutional petitioning activities.").

130. Saner, supra note 117, at 802-03. As Katelyn Saner noted, the First Circuit did not explicitly cite to Justice Ginsburg's Shady Grove dissent, but it followed her analysis by sharing her reluctance to find unnecessary conflict between federal and state laws, and by "look[ing] to past cases and history in finding no conflict." Id. at 802 n.157 (citing Godin, 629 F.3d at 86, 88).

131. Id. at 803; see Godin, 629 F.3d at 89-90.

132. Godin, 629 F.3d at 91 (quoting United States ex rel. Newsham v. Lockheed Missiles \& Space Co., 190 F.3d at 963, 972 (9th Cir. 1999)).

133. Id.

134. Id.

135. Id. at 88

136. Id.

137. Id.

138. Id. at 89 .

139. Id. at 91 (quoting United States ex rel. Newsham v. Lockheed Missiles \& Space Co., 190 F.3d at 963,972 (9th Cir. 1999)). 
Five years after Godin, the D.C. Circuit in Abbas reached the opposite conclusion and held that "[a] federal court exercising diversity jurisdiction ... must apply Federal Rules 12 and 56 instead of the D.C. Anti-SLAPP Act's special motion to dismiss provision." ${ }^{40}$ The D.C. Circuit reached this conclusion in part by finding that Rules 12 and 56 "establish the standards for granting pretrial judgment" in federal court. ${ }^{141}$ And, since the court found that Federal Rules 12 and 56 "answer the same question" as the D.C. anti-SLAPP statute, the court concluded that the two standards conflict with one another. ${ }^{142}$ Specifically, the Abbas court found that the D.C. anti-SLAPP statute "establishes the circumstances under which a court must dismiss a plaintiff's claim before trial - namely, when the court concludes that the plaintiff does not have a likelihood of success on the merits." 143 But Federal Rules 12 and 56, which also answer this question, do not impose any requirement that a plaintiff show a likelihood of success on the merits. ${ }^{144}$ The court concluded that the D.C. anti-SLAPP statute's "likelihood of success standard is different from and more difficult for plaintiffs to meet than the standards imposed by Federal Rules 12 and 56." ${ }^{145}$ Thus, the D.C. Circuit declined to apply the D.C. antiSLAPP statute in federal diversity actions. ${ }^{146}$

The diverging outcomes in Godin and Abbas exemplify the difficulties courts have faced in the wake of Shady Grove. However, the complexities left open in Shady Grove are not the sole reason for the disagreements among the circuit courts. The outcomes of anti-SLAPP motions in federal court also frequently turn on the particular language of the state statute. Although a circuit may resolve the applicability of one state's statute, this still leaves open questions about how the circuit may apply another state's statute. ${ }^{147}$

\footnotetext{
140. Abbas v. Foreign Policy Grp., LLC, 783 F.3d 1328, 1337 (D.C. Cir. 2015).

141. Id. at 1333.

142. Id. at $1333-34$.

143. Id. at 1333 .

144. Id. at $1333-34$.

145. Id. at 1335 .

146. Id. at 1332. Other courts have reached similar outcomes. See, e.g., Carbone v. Cable News Network, Inc., 910 F.3d 1345, 1356-57 (11th Cir. 2018) (holding that Georgia's anti-SLAPP motionto-strike provision conflicted with the Federal Rules because the provision was a purely procedural mechanism); Klocke v. Watson, 936 F.3d 240, 245 (5th Cir. 2019) (declining to apply the Texas antiSLAPP statute in federal court because it answers the same questions as Federal Rules 12 and 56); Los Lobos Renewable Power, LLC v. Americulture, Inc., 885 F.3d 659, 673 (10th Cir. 2018) (refusing to apply the New Mexico anti-SLAPP statute in federal court because it "simply does not define the scope of any state substantive right or remedy").

147. For example, in Intercon Solutions, Inc. v. Basel Action Network, the Seventh Circuit agreed with a district court's decision that the Washington anti-SLAPP statute was incompatible with the Federal Rules. 791 F.3d 729, 730 (7th Cir. 2015). However, the court recognized that "[ $t$ ] his circuit's
} 
The Tenth Circuit provides a clear example of where a circuit court determines the applicability of one state anti-SLAPP statute, but leaves unanswered the applicability of another state's anti-SLAPP law. In 2018, the Tenth Circuit held in Los Lobos Renewable Power, LLC $v$. AmeriCulture, Inc. that the New Mexico anti-SLAPP statute did not apply in federal court. ${ }^{148}$ However, later that year in Caranchini v. Peck, the U.S. District Court for the District of Kansas determined that Los Lobos was not binding precedent because the Tenth Circuit's finding was specific to the New Mexico statute. ${ }^{149}$ There, the court found that the Kansas antiSLAPP statute did apply in federal court. ${ }^{150}$ The distinction turned on the narrow language of the New Mexico statute, which provides:

Any action seeking money damages against a person for conduct or speech undertaken or made in connection with a public hearing or public meeting in a quasi-judicial proceeding ... is subject to a special motion to dismiss, motion for judgment on the pleadings, or motion for summary judgment that shall be considered by the court on a priority or expedited basis to ensure the early consideration of the issues raised by the motion and to prevent the unnecessary expense of litigation. ${ }^{151}$

This subsection is the key provision of the New Mexico statute, and notably, it does not set forth any rule of substantive law. ${ }^{152}$ Instead, it merely "tells the trial court to hurry up and decide dispositive pretrial motions" in frivolous SLAPPs and "creates a right to expeditious trial and appellate process." 153 Thus, the Los Lobos decision hinged on the unique and narrow language of the New Mexico anti-SLAPP statute. Because the statute is purely a "procedural mechanism for vindicating existing rights," its use in federal court would conflict with the Erie doctrine's requirement that federal law sitting in diversity apply federal procedural law. ${ }^{154}$

resolution of questions about how the procedural aspects of other states' anti-SLAPP statutes work in federal court will have to await some other case." Id. at 732.

148. 885 F.3d 659, 673 (10th Cir. 2018) ("A plain reading of the New Mexico anti-SLAPP statute reveals the statute is not designed to influence the outcome of an alleged SLAPP suit but only the timing of that outcome.").

149. 355 F. Supp. 3d 1052, 1057 (D. Kan. 2018) ("The Tenth Circuit's decision concerned only New Mexico's anti-SLAPP statute which, the court noted, was unlike many other states' anti-SLAPP statutes. The court's holding is therefore not binding on whether this court can apply the Kansas Act in a federal diversity action.").

150. Id. at 1061 .

151. N.M. StAT. ANN. § 38-2-9.1(A) (West, Westlaw through 2020 ch. 84 of 2d Reg. Sess.).

152. Los Lobos, 885 F.3d at 669 .

153. Id. at 669,666

154. Id. at 668-69 ("Fortunately, we need not rely on any complex Erie analysis here because, assuming one is able to read, drawing the line between procedure and substance in this case is hardly a 'challenging endeavor.' The plain language of the New Mexico anti-SLAPP statute reveals the law 
Similarly, the Fifth Circuit has reached divergent decisions regarding the applicability of two states' anti-SLAPP statutes. In Klocke v. Watson, the Fifth Circuit found that the Texas anti-SLAPP statute was not applicable in federal diversity actions because it directly conflicted with the Federal Rules. ${ }^{155}$ In contrast, in cases involving the Louisiana antiSLAPP statute, the Fifth Circuit has found that there is no "Erie problem." 156 The Fifth Circuit reached this determination after finding that the Texas statute "imposes higher and more complex preliminary burdens on the motion to dismiss process and imposes rigorous procedural deadlines." 157 These higher burdens include a burden-shifting framework that the Fifth Circuit determined "answers the same questions" as Federal Rules 12 and 56, as well as requirements demanding "judicial weighing of evidence." "158 But, the court reasoned that the Louisiana statute's less rigorous requirements - which place the same burden on a nonmovant in opposing the anti-SLAPP special motion as on a nonmovant opposing a motion for summary judgment — create less tension between the federal and state rules. ${ }^{159}$ These distinctions led the Fifth Circuit to determine that the tension "between the Texas law and the Federal Rules is manifest, while the comparable conflict between the Federal Rules and Louisiana law is less obvious." 160 Lastly, the Ninth Circuit has found that the California anti-SLAPP statute ${ }^{161}$ is applicable in federal diversity actions. ${ }^{162}$ The Ninth Circuit has the most robust body of case law addressing this issue, beginning in 1999 with United States ex rel. Newsham v. Lockheed Missiles \& Space Co. ${ }^{163}$ The Ninth Circuit's case law warrants its own discussion.

\footnotetext{
is nothing more than a procedural mechanism designed to expedite the disposal of frivolous lawsuits aimed at threatening free speech rights.").

155. 936 F.3d 240, 245 (5th Cir. 2019).

156. Lozovyy v. Kurtz, 813 F.3d 576, 582 (5th Cir. 2015) (citing Henry v. Lake Charles Am. Press, LLC, 566 F.3d 164, 168-69 (2009)); see also Block v. Tanenhaus, 815 F.3d 218, 221 (5th Cir. 2016) ("[W]e assume that [the Louisiana anti-SLAPP statute] does apply, and reject [the plaintiff's] argument that, because it provides a stricter standard than Rule 56, it does not apply in federal court. It provides the same standard as Rule 56; thus, there is no conflict on that basis.").

157. Klocke, 936 F.3d at 248.

158. Id. at $245-46$.

159. Id. at 249 (citing Block, 815 F.3d at 221).

160. Id. at $248-49$.

161. CAL. Civ. Pro. Code $\S 425.16$ (Deering 2019).

162. See United States ex rel. Newsham v. Lockheed Missiles \& Space Co., 190 F.3d 963, 973 (9th Cir. 1999).

163. Id.
} 


\section{The Ninth Circuit}

The Ninth Circuit first held that the California anti-SLAPP statute may apply in federal court in its 1999 United States ex rel. Newsham v. Lockheed Missiles \& Space Co. decision. ${ }^{164}$ There, the court concluded that although Federal Rules 12 and 56 served similar purposes to the California anti-SLAPP statute, there was no "direct collision" because the relevant provisions of the California anti-SLAPP statute promoted substantive interests. ${ }^{165}$ The court found that the "twin aims" of the Erie doctrine - the discouragement of forum shopping and promoting the equitable administration of justice - were best served by applying the California anti-SLAPP statute in federal court. ${ }^{166}$ The court reasoned that the "'special motion to strike' adds an additional, unique weapon to the pretrial arsenal, a weapon whose sting is enhanced" by allowing a SLAPP defendant to recover fees and costs. ${ }^{167}$ And, the court cautioned, a failure to apply the California anti-SLAPP statute in federal court would give a plaintiff a "significant incentive to shop for a federal forum," while giving a SLAPP defendant a "considerable disadvantage" - an outcome that "run[s] squarely against the 'twin aims' of the Erie doctrine."168 Although the Ninth Circuit still allows the California anti-SLAPP statute to apply in federal court, it has since released a string of opinions that indicate an attempt to restrict the scope of the statute's applicability in federal diversity actions. ${ }^{169}$

In 2001, the Ninth Circuit held in Metabolife International Inc. $v$. Wornick that two provisions of the California anti-SLAPP statute did not apply in federal diversity actions because they conflicted with the Federal Rules. ${ }^{170}$ These two provisions provided that the anti-SLAPP motion may be filed within sixty days of filing the complaint or, at the court's discretion, at any later date, ${ }^{171}$ and that the filing of an anti-SLAPP motion automatically stays all further discovery until the court rules on the

\footnotetext{
164. Id. at 973 .

165. Id. at 972 .

166. Id. at 973 .

167. Id.

168. Id.

169. See Metabolife Int'l, Inc. v. Wornick, 264 F.3d 832, 845-47 (9th Cir. 2001); Makaeff v. Trump Univ., LLC, 715 F.3d 254, 272-75 (9th Cir. 2013) (Kozinski, J., concurring); Planned Parenthood Fed'n of Am., Inc. v. Ctr. for Med. Progress, 890 F.3d 828, 832-35 (9th Cir. 2018), cert. denied, 139 S. Ct. 1446 (2019).

170. 264 F.3d at 846 (quoting Rogers v. Home Shopping Network, Inc., 57 F. Supp. 2d 973, 982 (C.D. Cal. 1999)).

171. Cal. Civ. Pro. Code $\S 425.16$ (f) (Deering 2019).
} 
motion, unless the court specified discovery for good cause shown. ${ }^{172}$ The Ninth Circuit found that, "[t]ogether, these two subsections "create a default rule that allows the defendant served with a complaint to immediately put the plaintiff to his or her proof before the plaintiff can conduct discovery," "whereas Federal Rule 56 does not limit discovery. ${ }^{173}$ The court stated:

Section 425.16 limits discovery and makes further discovery an exception, rather than the rule. Rule 56 does not limit discovery. On the contrary, it ensures that adequate discovery will occur before summary judgment is considered.

Because the discovery-limiting aspects of $\S 425.16(\mathrm{f})$ and $(\mathrm{g})$ collide with the discovery-allowing aspects of Rule 56, these aspects of subsections (f) and (g) cannot apply in federal court. ${ }^{174}$

By imposing these limits, Metabolife became the first Ninth Circuit case to begin circumscribing the scope of the California anti-SLAPP statute in federal diversity actions.

Several years later, in Makaeff $v$. Trump University, LLC, the Ninth Circuit again returned to the question of the applicability of the California anti-SLAPP statute in federal diversity actions. ${ }^{175}$ In Makaeff, the Ninth Circuit overturned the district court's denial of a plaintiff's motion to strike. ${ }^{176}$ The decision included what has become a very influential concurrence by then-Chief Judge Alex Kozinski, creating some uncertainty about the future of the California anti-SLAPP statute's applicability in federal diversity actions. ${ }^{177}$ In his concurrence, Judge Kozinski explicitly stated that Newsham "was a big mistake" and "is wrong and should be reconsidered" because "the [California] anti-SLAPP statute creates no substantive rights; it merely provides a procedural mechanism for vindicating existing rights." ${ }^{\prime 78} \mathrm{He}$ asserted that the Federal Rules "provide an integrated program of pre-trial, trial and post-trial

\footnotetext{
172. $I d . \S 425.16(\mathrm{~g})$.

173. Metabolife, 264 F.3d at 846 (quoting Rogers, 57 F. Supp. 2d at 980).

174. Id. (quoting Rogers, 57 F. Supp. 2d at 982).

175. 715 F.3d 254 (9th Cir. 2013).

176. Id. at 271-72.

177. See, e.g., Abbas v. Foreign Policy Grp., LLC, 783 F.3d 1328, 1335-36 (D.C. Cir. 2015) ("[W]e agree with Judge Kozinski and Judge Watford that [Godin, Henry, and Newsham] are ultimately not persuasive." (citing Makaeff, 715 F.3d at 275 (Kozinski, J., concurring); Makaeff v. Trump Univ., LLC, 736 F.3d 1180, 1188 (9th Cir. 2013) (Watford, J., dissenting))); Klocke v. Watson, 936 F.3d 240, 247 (5th Cir. 2019) (endorsing Judge Kozinski's characterization of the California antiSLAPP law as a purely procedural statute that creates no substantive rights and stating that his characterization "pertains equally" to the Texas anti-SLAPP law).
}

178. Makaeff, 715 F.3d at 272-75 (Kozinski, J., concurring). 
procedures designed to ... follow a logical order and pace so that cases proceed smartly towards final judgment or settlement," and that application of the California statute "cuts an ugly gash through this orderly process." "179 His fiery concurrence has since been referenced by other courts that have decided not to apply anti-SLAPP statutes in federal diversity actions. ${ }^{180}$ Further, the Ninth Circuit has subsequently appeared more willing to adopt Judge Kozinski's reasoning and restrict the scope of the statute's applicability.

The most recent Ninth Circuit case to address the issue is Planned Parenthood Federation of America, Inc. v. Center for Medical Progress, which further narrowed the applicability of the California anti-SLAPP statute. ${ }^{181}$ There, the plaintiffs sued the defendants in federal court, alleging that the defendants fraudulently entered Planned Parenthood staff conferences and meetings to create fabricated and deceptive videos that were then posted online. ${ }^{182}$ The defendants moved to dismiss under Federal Rule 12(b)(6) and under the California anti-SLAPP statute. ${ }^{183}$ The district court denied both motions, and the Ninth Circuit affirmed. ${ }^{184}$ In reaching this conclusion, the Ninth Circuit relied on its prior analysis in Metabolife, where the court held that some portions of California's antiSLAPP law - the automatic stay of discovery and the time requirementsconflict with the Federal Rules. ${ }^{185}$ The Ninth Circuit decided that it would apply different standards of review to anti-SLAPP motions to strike depending on the basis of the motion "to prevent the collision of California state procedural rules with federal procedural rules." "The court adopted the following language from a prior unpublished opinion:

If a defendant makes an anti-SLAPP motion to strike founded on purely legal arguments, then the analysis is made under Fed. R. Civ. P. 8 and 12 standards; if it is a factual challenge, then the motion must be treated as though it were a motion for summary judgment and discovery must be permitted. ${ }^{187}$

Metabolife and Center for Medical Progress, taken together, suggest that a plaintiff need not put forth prima facie evidence supporting its claims if

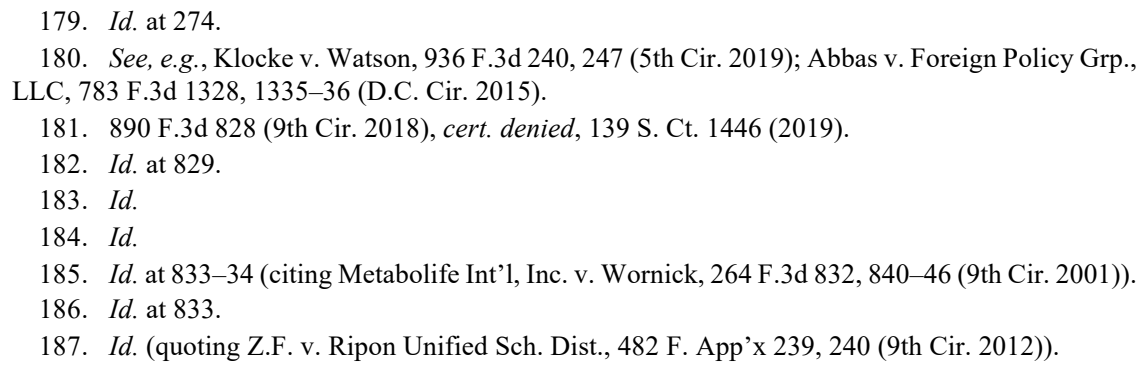


a defendant's anti-SLAPP motion is based on a complaint's legal deficiencies. ${ }^{188}$ Without accompanying discovery, this requirement "would improperly transform the motion to strike under the anti-SLAPP law into a motion for summary judgment without providing any of the procedural safeguards that have been firmly established by the Federal Rules of Civil Procedure." 189 Looking to the basis of the motion to determine the appropriate standard of review when analyzing anti-SLAPP motions to strike would allow the anti-SLAPP protections to remain in place while maintaining the procedural safeguards established by the Federal Rules.

\section{E. The U.S. District Court for the District of Kansas}

Unlike the Ninth Circuit's well-developed case law regarding the California anti-SLAPP statute, only one case has discussed the Kansas anti-SLAPP statute's applicability in federal diversity actions. ${ }^{190}$ In 2018, the U.S. District Court for the District of Kansas decided Caranchini v. Peck, where the Kansas anti-SLAPP statute's applicability in federal court was a question of first impression. ${ }^{191}$ In evaluating the statute's applicability, the court determined that the Kansas anti-SLAPP statute governed both substance and procedure. ${ }^{192}$ After quickly deciding that the Tenth Circuit's Los Lobos decision did not control, the court turned to additional circuit court analyses of other state anti-SLAPP statutes. ${ }^{193}$ The court focused primarily on the First Circuit's opinion in Godin v. Schencks ${ }^{194}$ and the D.C. Circuit's opinion in Abbas v. Foreign Policy Group, $L L C,{ }^{195}$ because the state statutes at issue in those cases have similar burden shifting frameworks to the Kansas anti-SLAPP statute. ${ }^{196}$ The court agreed with the First Circuit that "the application of the antiSLAPP statute in federal diversity actions would best serve the "twin aims for the Erie rule: discouragement of forum shopping and inequitable administration of the laws." 197 The court reasoned that a failure to apply the Kansas anti-SLAPP statute would ignore the Kansas legislature's desire to provide additional protection to SLAPP defendants, and therefore

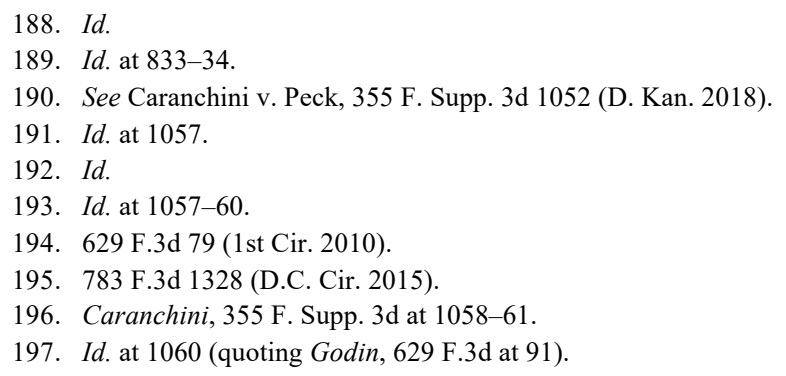


concluded that applying the statute in federal diversity actions was most consistent with the Erie doctrine's purposes. ${ }^{198}$ The court found that, although procedural in nature, the statute "exist[s] to influence substantive outcomes, and ... is so bound up with the state-created right or remedy that it defines the scope of that substantive right or remedy."199 The U.S. District Court for the District of Kansas expressed confidence that the Tenth Circuit would agree with this outcome based on dicta in Los Lobos suggesting that burden-shifting provisions in anti-SLAPP statutes "are more substantive in nature ... and are [therefore] more likely to apply in federal diversity actions." 200 The court also asserted that it did not find the reasoning in Abbas persuasive, because it disagreed with the D.C. Circuit's view that the D.C. statute is "very procedural in nature" since it "creates a mechanism for a defendant to resolve the case pre-trial, much like Rules 12 and 56." 201 The Caranchini court also found that the D.C. Circuit should have discussed the "practical effects" of failing to apply the antiSLAPP statutes in federal diversity actions. ${ }^{202}$ Thus, after evaluating the Godin and Abbas decisions, the court concluded that applying the Kansas anti-SLAPP statute in federal court "is the result that is most consistent with the purposes of the Erie doctrine."203

\section{ANALYSIS}

The sole case from the U.S. District Court for the District of Kansas addressing the applicability of Kansas's anti-SLAPP statute in federal court lacks the depth of the more well-developed Ninth Circuit case law. As the U.S. District Court for the District of Kansas continues to develop its approach on this issue, it should follow the Ninth Circuit's recent efforts to circumscribe select procedural provisions of the state anti-SLAPP statute, while continuing to apply its substantive provisions, because this

198. Id.

199. Id. at 1061 (quoting Shady Grove Orthopedic Assocs., P.A. v. Allstate Ins. Co., 559 U.S. 393, 419-20 (2010) (Stevens, J., concurring)).

200. Id. Other district courts in the Tenth Circuit have also found anti-SLAPP statutes applicable in federal diversity actions despite the Los Lobos decision. See, e.g., Barnett v. Hall, No. 18-cv-00064, 2018 WL 4038117, at *3 (N.D. Okla. Aug. 23, 2018) (finding Los Lobos did not control whether the Oklahoma anti-SLAPP statute applies in federal court because "Los Lobos [was] carefully limited to the New Mexico statute it addresse[d]"). Barnett noted that "Los Lobos also repeatedly contrast[ed] the New Mexico statute with the California anti-SLAPP statute, noting that the California statute shifted substantive burdens and altered substantive standards," and found that although the Oklahoma anti-SLAPP statute employs "distinct substantive standards, it employs the same burden shifting structure as California." Id.

201. Caranchini, 355 F. Supp. 3d at 1060-61.

202. Id. at 1061 .

203. Id. 
best aligns with the purposes of the Erie doctrine. This Part will consider the similarities between the California and Kansas anti-SLAPP statutes, describe how circumscribing only the procedural provisions of the Kansas statute aligns with the Erie doctrine and its goals, and conclude by evaluating the implications of adopting the Ninth Circuit's approach.

\section{A. The Kansas Anti-SLAPP Statute Is Similar to Its California Counterpart}

The Kansas and California anti-SLAPP statutes contain many strikingly similar provisions. This Section discusses the similarities between the two statutes' stated purposes and the protected activities that they cover.

\section{The Stated Purposes Are Similar}

The Kansas anti-SLAPP statute's language more closely resembles the broad language of the California anti-SLAPP statute than some of the more narrow provisions found in several other state statutes. The Kansas statute is designed to "encourage and safeguard the constitutional rights of a person to petition, and speak freely and associate freely, in connection with a public issue or issue of public interest." 204 Similarly, the California statute's stated purpose is to protect an individual's "right of petition or free speech under the United States Constitution . . . in connection with a public issue." 205 The California legislature elaborated even further, stating at the statute's outset:

The Legislature finds and declares that there has been a disturbing increase in lawsuits brought primarily to chill the valid exercise of the constitutional rights of freedom of speech and petition for the redress of grievances. The Legislature finds and declares that it is in the public interest to encourage continued participation in matters of public significance, and that this participation should not be chilled through abuse of the judicial process. To this end, this section shall be construed broadly. ${ }^{206}$

The Kansas legislature did not elaborate as extensively as the California legislature, but the Kansas statute similarly directs courts to "appl[y] and construe[]" its provisions "liberally to effectuate its general purposes."

\footnotetext{
204. KAN. StAT. ANN. § 60-5320(b) (West 2016 \& Supp. 2019).

205. CAL. Civ. Proc. CODE $\S 425.16(\mathrm{~b})(1)$ (Deering 2019).

206. Id. § 425.16(a) (emphasis added).

207. KAN. STAT. ANN. $§ 60-5320(\mathrm{k})$; see also Jana S. Baker \& Victoria L. Vish, The Burgeoning
} 
2. The Kansas and California Statutes Apply to a Similar Array of Protected Activities

The Kansas and California anti-SLAPP statutes both provide safeguards for a similar range of constitutionally protected activities. The Kansas statute provides an extensive list of the communications that fall under the statute's protection, including a wide variety of communications pertaining to judicial, official, executive, legislative, and various other types of proceedings. ${ }^{208}$ Similarly, California's statute protects acts conducted "in furtherance of a person's right of petition or free speech," including written or oral statements concerning legislative, executive, judicial, or any other official proceedings, as well as any "statement or writing made in a place open to the public or a public forum in connection with an issue of public interest." ${ }^{209}$ Lastly, the California statute, like Kansas, provides for the recovery of attorney's fees and litigation costs of a party that wins a motion to dismiss under the statute. ${ }^{210}$

Although the text of the California and Kansas anti-SLAPP statutes closely resemble each other, the Public Participation Project (the "Project") - a prominent organization heavily involved in First Amendment advocacy that advocates for heightened free speech protection-gives the California statute an "excellent" rating and the Kansas statute a "good" rating. ${ }^{211}$ On the Project's "State Anti-SLAPP Scorecard" the California statute has a letter grade of "A," (which corresponds to an "excellent" rating) whereas the Kansas statute was given a letter grade of "B," (which corresponds to a "good" rating). ${ }^{212}$ However, comparing the Kansas statute with state statutes that are considered "adequate" or "weak" by the Project and have letter grades of "C" or "D," respectively, illustrates how the Kansas statute much more closely resembles the California statute. For example, the Arizona anti-SLAPP statute has an "adequate" rating with a "C" letter grade because it protects

\footnotetext{
Use of "Strong" Anti-SLAPP Statutes in Employment Law, OGLETREe DeAKINS (Mar. 6, 2019), https://ogletree.com/insights/2019-03-06/the-burgeoning-use-of-strong-anti-slapp-statutes-in-employ ment-law/ [https://perma.cc/63KR-EH7S] ("One of the strongest anti-SLAPP statutes is the Texas Citizens Participation Act (TCPA).... The TCPA explicitly instructs courts to construe its provisions liberally 'to effectuate its purpose and intent fully.' ... But not all statutes are created equal. In contrast to the language contained in the Texas and California anti-SLAPP statutes, states such as New York have narrowly worded anti-SLAPP statutes that naturally limit their scope and applicability." (quoting TEX. CIV. PRAC. \& REM. CODE ANN. § 27.011(b) (West, Westlaw current through 2019 Reg. Sess.))).

208. KAN. STAT. ANN. § 60-5320(c)(5).

209. CAL. CIV. Proc. CODE $\S 425.16(\mathrm{e})$.

210. Id. § 425.16(c)(1); KAN. STAT. ANN. § 60-5320(g)(1).

211. Project, supra note 12.

212. Id.
} 
a narrower range of activities. ${ }^{213}$ The Arizona statute protects an individual's right to petition; but, unlike the Kansas and California statutes, the phrase "exercise of the right of petition" is limited only to statements that are either "made as part of an initiative, referendum or recall effort," or statements that are made before a governmental body or proceeding, connected to "an issue that is under consideration or review," and " $[\mathrm{m}]$ ade for the purpose of influencing a governmental action, decision or result." 214 Thus, a defendant can only challenge a lawsuit as a SLAPP under the Arizona statute if the defendant made or submitted the statement in one of these two specific instances. ${ }^{215}$ Several other states that received lower ratings from the Project have similar restrictions and narrow protective scopes. ${ }^{216}$

\section{B. The Erie Doctrine Requires Application of the Kansas Anti-SLAPP Statute in Federal Court}

As discussed above, the Erie doctrine is a complex area of law that has evolved significantly since its inception in $1938 .^{217}$ Despite its complexity, the current doctrine provides some guidance to courts attempting to resolve the tension between the Kansas anti-SLAPP statute and the Federal Rules. In determining whether a state law may apply in federal diversity actions, courts first assess whether the Constitution or any federal statute, treaty, or Federal Rule applies - and if so, this law controls. ${ }^{218}$ When an apparent conflict exists between state and a Federal Rule, courts consider whether the Federal Rule can be construed narrowly so as to avoid conflict with the state rule. ${ }^{219}$ If the conflict cannot be avoided by narrow construction, then the court considers whether the choice between federal and state law would be outcome-determinative under Guaranty Trust. .20 $^{2}$ The court should here consider the "twin aims" of Erie to see if a failure to apply the state law would result in forum

\footnotetext{
213. Id.

214. ARIZ. ReV. StAT. ANN. § 12-751(1) (West, Westlaw through 2d Reg. Sess. of 54th Legis.).

215. Id. § 12-752(A).

216. Project, supra note 12. See, e.g., 27 PA. Cons. STAT. ANN. §§ 7707, 8301-8305 (West, Westlaw through 2020 Reg. Sess.) (applying only to individuals petitioning the government over environmental issues); NEB. REV. STAT. ANN. $\S \S 25-21,243$ to $-21,246$ (West, Westlaw through legislation effective Mar. 26, 2020) (applying only to applicants for government permits, providing no explicit motion to dismiss nor discovery stay provision, and leaving attorney's fees to the court's discretion).

217. See supra Section II.C.1.

218. Hanna v. Plumer, 380 U.S. 460, 465 (1965).

219. Id. at $472-73$.

220. Guar. Tr. Co. v. York, 326 U.S. 99, 111-112 (1945).
} 
shopping or an inequitable administration of the laws. ${ }^{221}$ If the choice of law would not influence the outcome of the case, then the federal law would control, but if the choice would be outcome-determinative, the court looks to the test articulated in Byrd to see if any important countervailing federal interest exists that would require the application of federal law. ${ }^{22}$ A substantive state law will apply in federal diversity actions unless there is a "federal policy favoring" the Federal Rule, ${ }^{223}$ because even when the state statute presumptively applies, Byrd allows a Federal Rule to still trump the state law if there is an important federal policy at stake. ${ }^{224}$ But, federal courts should supplant state law only as much as is necessary to maintain the essential characteristics of the federal system. ${ }^{225}$ Following this analysis, as demonstrated below, would lead a court to determine that applying the Kansas anti-SLAPP statute's substantive provisions in federal diversity actions serves Erie's purpose of promoting federal and state interests.

1. A Narrow Construction of the Federal Rules Alleviates Any Existing Tension with the Kansas Statute

The Erie doctrine requires federal courts sitting in diversity to apply the Kansas anti-SLAPP statute. To determine whether a state law may apply in federal diversity actions, courts must assess whether the Constitution or any federal statute, treaty, or Federal Rule applies - and if so, this law controls. ${ }^{226}$ When an apparent conflict exists between a state law and a Federal Rule, courts consider whether the Federal Rule can be construed narrowly so as to avoid conflict with the state rule. ${ }^{227}$

Federal Rules 8, 12, and 56 can be construed narrowly so as to avoid conflict with most provisions in the Kansas anti-SLAPP statute, because the Kansas statute governs only narrow factual situations where a defendant is defending its First Amendment right to petition. The Kansas statute allows a defendant to bring early motions to strike claims based on, related to, or brought "in response to a party's exercise of the right of free speech, right to petition or right of association." ${ }^{228}$ In such cases, the

221. See Hanna, 380 U.S. at 468 ("The 'outcome-determination' test therefore cannot be read without reference to the twin aims of the Erie rule: discouragement of forum-shopping and avoidance of inequitable administration of the laws.").

222. See Byrd v. Blue Ridge Elec. Coop., Inc., 356 U.S. 525, 538 (1958).

223. Id. at 538 .

224. Id.

225. Gasperini v. Ctr. for Humanities, Inc., 518 U.S. 415, 431 (1996).

226. Hanna, 380 U.S. at 465 .

227. Id. at 472-73.

228. KAN. Stat. ANN. § 60-5320(d) (West 2016 \& Supp. 2019). 
statute requires a plaintiff to put forth a heightened showing that it could prevail. $^{229}$ If the plaintiff fails to meet this burden, the claims must be dismissed. ${ }^{230}$ Federal Rules 8, 12, and 56 govern the pleading and pretrial dismissal procedure in federal civil suits, but these Federal Rules can coexist with the Kansas anti-SLAPP statute because the Kansas statute seeks to advance a substantive policy of protecting free speech, a goal that is nowhere mentioned in the Federal Rules. As Justice Ginsburg asserted in Shady Grove, a federal court hearing a diversity case can, and should, "accord due respect to both state and federal prescriptions," because the "Erie jurisprudence... counsels [the Court] to read Federal Rules moderately and cautions against stretching a Rule to cover every situation it could conceivably reach." ${ }^{231}$ Although Federal Rules 8, 12, and 56 could be stretched to conceivably reach every situation covered by the Kansas statute, the Federal Rules still fail to provide the substantive First Amendment protections afforded to individuals by the Kansas statute.

When tasked with resolving the apparent conflict between the Federal Rules and the Kansas statute, the U.S. District Court for the District of Kansas, and ultimately the Tenth Circuit, should adopt the approach that the Ninth Circuit took in Center for Medical Progress. There, to alleviate the tension between the Federal Rules and the California anti-SLAPP statute, the Ninth Circuit decided to review anti-SLAPP motions to dismiss under two different standards depending on the motion's basis. The court stated that when an anti-SLAPP motion to strike is "founded on purely legal arguments, then the analysis is made under [Federal Rules] 8 and 12 standards; if it is a factual challenge, then the motion must be treated as though it were a motion for summary judgment and discovery must be permitted." "232 But, if the motion to strike is "based on alleged deficiencies in the plaintiff's complaint, the motion must be treated in the same manner as a motion under Rule 12(b)(6) except that the attorney's fee provision of $\S 425.16$ (c) applies." 233 Thus, if an anti-SLAPP motion to dismiss is brought challenging a complaint's legal sufficiency, a federal court should evaluate the motion using the pleading requirements found in Federal Rules 8 and 12. But, if the motion challenges a complaint's factual basis, then the court should evaluate it as a Federal Rule 56 summary

229. Id.

230. Id.

231. Shady Grove Orthopedic Associates, P.A. v. Allstate Ins. Co., 559 U.S. 393, 449-50 (2010) (Ginsburg, J., dissenting).

232. Planned Parenthood Fed'n of Am., Inc. v. Ctr. for Med. Progress, 890 F.3d 828, 833 (9th Cir. 2018) (quoting Z.F. Ripon Unified Sch. Dist., 482 F. App'x 239, 230 (9th Cir. 2012)), cert. denied, 139 S. Ct. 1446 (2019).

233. Id. at 834 (quoting Rogers v. Home Shopping Network, Inc., 57 F. Supp. 2d 973, 983 (C.D. Cal. 1999)). 
judgment motion and allow for appropriate discovery. This result would be in line with the guidelines set out in the Kansas statute. ${ }^{234}$ The Ninth Circuit's construction squares with the federal courts' responsibility to interpret the Federal Rules "with sensitivity to important state interests and regulatory policies" 235 by applying the Federal Rules narrowly so as to avoid conflict with the provisions in the Kansas anti-SLAPP statute.

2. Allowing the Substantive Provisions of the Kansas Statute to Apply in Diversity Actions Promotes State Interests

If the Kansas statute did not apply in federal diversity actions, this would give plaintiffs a choice between federal and state law that would be considered outcome-determinative under Guaranty Trust. ${ }^{236}$ This choice is outcome-determinative if a plaintiff would perceive she would receive different outcomes in her case if federal law was applied instead of the state law. If the plaintiff would perceive no difference in her case under either law, then the federal law should apply. Here, a plaintiff bringing a SLAPP would undoubtedly choose the federal forum if the Kansas antiSLAPP statute did not apply to her case. Therefore, the applicability of the Kansas statute must be assessed in light of the "twin aims" of Erie"discouragement of forum-shopping and avoidance of inequitable administration of the laws." 237 Failure to apply the clearly substantive provisions of the Kansas anti-SLAPP statute would lead to inequitable administration of justice between a party's options in state and federal court. Equitable administration of the laws compels federal courts sitting in diversity to apply the Kansas anti-SLAPP statute, because a contrary result would require a federal court to ignore the additional protections enacted by the Kansas legislature when applying Kansas defamation laws solely by virtue of "the accident of diversity of citizenship." 238 The Erie rule is founded on the principle that the result of litigation should not be different just because a case is brought in federal court. ${ }^{239}$ In declining to apply the statute, a federal court would "ignor[e] the Kansas legislature's desire to protect individuals against defamation lawsuits that infringe on [their] First Amendment rights" and defy the power of the legislature "to

234. KAN. STAT. ANN. $§ 60-5320(\mathrm{e})(1)$ (permitting a court to allow discovery in anti-SLAPP motions to dismiss)

235. Gasperini v. Ctr. for Humanities, Inc., 518 U.S. 415, 427 n.7 (1996).

236. See Guar. Tr. Co. v. York, 326 U.S. 99, 111-112 (1945).

237. Hanna v. Plumer, 380 U.S. 460, 468 (1965).

238. Klaxon Co. v. Stentor Elec. Mfg. Co., 313 U.S. 487, 496 (1941).

239. Hanna, 380 U.S. at 467. 
create additional rules that govern its laws and causes of action." 240 This would leave a federal SLAPP defendant unable to invoke the additional protections envisioned by the Kansas legislature when it enacted the statute, a result that leads to an inequitable administration of the laws.

Allowing a defendant to invoke the Kansas anti-SLAPP statute in federal diversity actions discourages forum shopping by subjecting parties to the same law in both forums. Failure to apply the Kansas anti-SLAPP statute in federal diversity actions would frustrate Erie's purpose of discouraging forum shopping because a party bringing its lawsuit in federal court would be able to avoid the burden-shifting provisions in the statute as well as evade liability for the defendant's attorney's fees, as is provided under the statute. ${ }^{241}$ Therefore, because a plaintiff's choice of forum would be influenced depending on the applicability of the statute, the Kansas statute should be uniformly applied in both state and federal courts. ${ }^{242}$

However, a few provisions in the Kansas statute, such as the stay on discovery and the timeliness requirements, appear purely procedural. ${ }^{243}$ Therefore, federal courts sitting in diversity need not apply these few specific statutory provisions. Later sections will discuss these procedural provisions and explore how the Ninth Circuit's case law on this issue may provide guidance to courts confronting these provisions in the Kansas antiSLAPP statute. ${ }^{244}$

\section{No Sufficiently Important Federal Interests Exist That Would}

Prohibit Application of the Kansas Statute in Federal Court

Once the choice between federal and state law is deemed outcomedeterminative, under Byrd the court asks if any important countervailing federal interest exists that would require the application of federal law. ${ }^{245}$ A substantive state law will apply in federal diversity actions unless there

240. Caranchini v. Peck, 355 F. Supp. 3d 1052, 1060 (D. Kan. 2018).

241. Kan. STAT. ANN. $§ 60-5320(\mathrm{~g})(1)$ (West $2016 \&$ Supp. 2019).

242. See Godin v. Schencks, 629 F.3d 79, 92 (1st Cir. 2010) ("Declining to apply [the Maine antiSLAPP statute] in federal court would thus result in an inequitable administration of justice between a defense asserted in state court and the same defense asserted in federal court. Likewise, were [the Maine statute] not to apply in federal court, the incentives for forum shopping would be strong: electing to bring state-law claims in federal as opposed to state court would allow a plaintiff to avoid [the statute]'s burden-shifting framework, rely upon the common law's per se damages rule, and circumvent any liability for a defendant's attorney's fees or costs.").

243. KAN. STAT. ANN. § 60-5320(d), (e)(2).

244. See infra Section III.C.

245. See Byrd v. Blue Ridge Elec. Coop., Inc., 356 U.S. 525, 538 (1958); see also supra Section II.C.1. 
is a "federal policy favoring" the Federal Rule, ${ }^{246}$ because even when the state statute presumptively applies, Byrd allows a Federal Rule to still trump the state law if there is an important federal policy at stake. ${ }^{247}$ But, federal courts should supplant state law only as much as is necessary to maintain the essential characteristics of the federal system. ${ }^{248}$ Although federal courts have an interest in promoting uniformity, this interest does not outweigh Kansas's interest in providing additional protection for individuals facing meritless SLAPP suits for exercising their First Amendment rights. As one author asserted, federalism principles and First Amendment rights afforded to individuals "outweigh the generalized interest in uniformity of federal procedure, especially when such uniformity in procedure has the potential to create disuniformity in outcome by undermining state law protections for legitimate petitioning activity." ${ }^{249}$ Therefore, courts facing this question should not find that any countervailing federal interests are strong enough to outweigh application of the Kansas anti-SLAPP statute in federal diversity actions.

\section{The U.S. District Court for the District of Kansas Should Imitate the Ninth Circuit's Recent Restrictions and Employ Only the Substantive Provisions in Federal Diversity Actions}

In Caranchini v. Peck, the U.S. District Court for the District of Kansas found that the Kansas anti-SLAPP statute did not create a substitute for Rules 12 and 56, but "merely supplement[ed] them for a narrow category of cases." ${ }^{250}$ However, the court noted in dicta it was "not convinced that the requirement that a court hold a hearing within 30 days and the mandatory discovery stay provisions are applicable in federal diversity actions, as those provisions are strictly procedural in nature and do not affect the outcome of the case." ${ }^{251}$ The court, however, did not reach any conclusions on this point because neither party raised the issue. ${ }^{252}$ In future cases that do raise this issue, the U.S. District Court for the District of Kansas should look to the Ninth Circuit's string of decisions that discuss the variances between the California anti-SLAPP statute's procedural and substantive provisions.

\footnotetext{
246. Byrd, 356 U.S. at 538.

247. Id.

248. Gasperini v. Ctr. for Humanities, Inc., 518 U.S. 415, 431 (1996).

249. Quinlan, supra note 55, at 403.

250. Caranchini v. Peck, 355 F. Supp. 3d 1052, 1061 (D. Kan. 2018).

251. Id. (citing Metabolife Int'l, Inc. v. Wornick, 264 F.3d 832, 845-46 (9th Cir. 2001)).

252. Id.
} 
1. The Timeliness Requirements

United States ex rel. Newsham v. Lockheed Missiles \& Space Co. ${ }^{253}$ was the first Ninth Circuit case to find no direct conflict between the Federal Rules and the California anti-SLAPP statute's provisions offering defendants a special motion to strike ${ }^{254}$ and the availability of fees and costs. $^{255}$ But Newsham did not address the rest of the California antiSLAPP statute. ${ }^{256}$ Two years later, the Ninth Circuit found that the discovery restrictions in the California anti-SLAPP statute conflict with the "discovery-allowing aspects" of Federal Rule 56, and therefore those provisions of the California statute could not apply in federal court. ${ }^{257}$ The Ninth Circuit reached the same conclusion again in Center for Medical Progress regarding the applicability of the statute's timing requirements in federal proceedings. ${ }^{258}$ This is one of the ways the Ninth Circuit has placed restrictions on the scope of the California anti-SLAPP statute in federal court.

Kansas's anti-SLAPP statute includes a strikingly similar provision. Subsection (d) states "[t]he motion to strike made under this subsection may be filed within 60 days of the service of the most recent complaint," and "[a] hearing shall be held on the motion not more than 30 days after the service of the motion." ${ }^{259}$ The court in Caranchini v. Peck did not rule on the applicability of this provision because it was not raised as an issue. ${ }^{260}$ When presented with this issue, the U.S. District Court for the District of Kansas should adopt the Ninth Circuit's analysis in Metabolife and Center for Medical Progress and determine that this provision is a purely procedural mechanism, and therefore not applicable in federal diversity actions.

\section{The Automatic Stay on Discovery}

Another provision of the California statute that the Ninth Circuit determined inapplicable in federal court is the automatic stay on discovery. The Metabolife court explained that district courts in the Ninth Circuit have found that an automatic stay conflicts with the Rule 56 summary

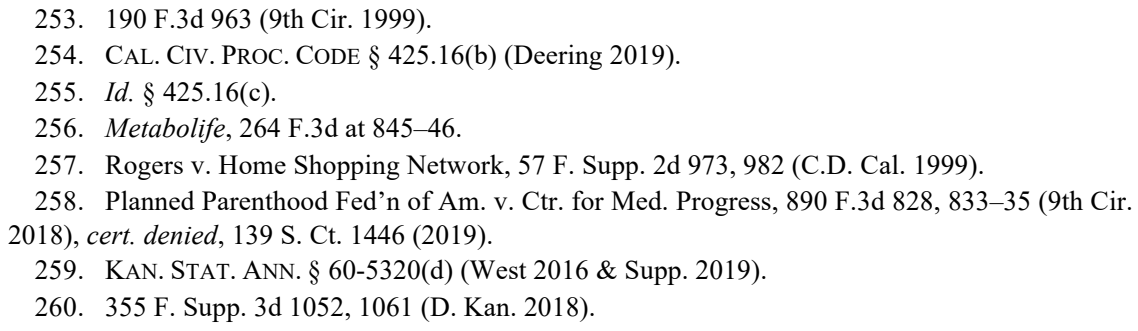


judgment requirements, and therefore is inapplicable in federal court. ${ }^{261}$ The court reasoned that the provisions limiting discovery in the California statute collide with the "discovery-allowing aspect of Rule 56" and therefore cannot apply in federal diversity actions. ${ }^{262}$

Other courts have similarly found the discovery-limiting provisions in other states' anti-SLAPP statutes inapplicable in federal diversity actions. For example, in 2015, the U.S. District Court for the District of Minnesota held that the Minnesota anti-SLAPP law "collides head-on" with Federal Rule 56. ${ }^{263}$ The court found that the restrictive standard for discovery under the Minnesota anti-SLAPP statute is "oil to the water of Rule 56's more permissive standard." 264 The Minnesota statute suspended discovery pending the motion's final disposition, "provided that the court may, on motion and after a hearing and for good cause shown, order that specified and limited discovery be conducted." 265 The court concluded that because Rule 56 did not place the same "hurdle in the path of a party seeking" discovery to avoid pretrial dismissal of its well-pleaded claims, it would not apply the discovery rule in Minnesota's anti-SLAPP law. ${ }^{266}$

The Kansas statute also provides for a discovery stay:

[A]11 discovery, motions or other pending hearings shall be stayed upon the filing of the motion to strike. The stay of discovery shall remain in effect until the entry of the order ruling on the motion except that the court, on motion and for good cause shown, may order that specified discovery, motions or other pending hearings be conducted. ${ }^{267}$

This provision, much like the discovery-limiting provisions of the

261. Metabolife, 264 F.3d at 846.

262. Id.

263. Unity Healthcare, Inc. v. County of Hennepin, 308 F.R.D. 537, 541 (D. Minn. 2015).

264. Id.

265. Id. (quoting MinN. STAT. ANN. § 554.02 (West, Westlaw through Mar. 31, 2020 legislation)). "Rule 56 makes discovery the norm and 'ensures that adequate discovery will occur before summary judgment is considered.' The anti-SLAPP law makes discovery the exception and forces a 'court to test the plaintiff's evidence before the plaintiff has completed discovery."' Id. (first quoting Metabolife, 264 F.3d at 846; and then quoting Rogers v. Home Shopping Network, Inc., 57 F. Supp. 2d 973, 980 (C.D. Cal. 1999)).

266. Id. Note that the following year, the Minnesota Court of Appeals found the procedural provisions of Minnesota's anti-SLAPP law unconstitutional because they "deprive[d] the non-moving party of the right to a jury trial by requiring a court to make pretrial factual findings to determine whether the moving party is immune from liability." Mobile Diagnostic Imaging, Inc. v. Hooten, 889 N.W.2d 27, 35 (Minn. Ct. App. 2016). In 2017, the Minnesota Supreme Court agreed. See Leiendecker v. Asian Women United of Minn., 895 N.W.2d 623, 637 (Minn. 2017) (finding that the Minnesota anti-SLAPP statute was "unconstitutional as applied to claims at law alleging torts" because "[a]llowing equitable immunities that are identical to a plaintiff"s cause of action would permit the Legislature to erode the jury-trial right by sleight of hand").

267. KAN. StaT. ANN. § 60-5320(e)(2) (West $2016 \&$ Supp. 2019). 
California and the Minnesota statutes, likely conflicts with Federal Rule 56 in such a way that even a narrow construction of Rule 56 would fail to alleviate the tension.

Although the Kansas anti-SLAPP statute's substantive provisionsthe special motion to strike and the availability of attorney's fees and costs - should remain applicable in federal diversity actions, the timing requirements and the automatic stay on discovery likely create an unresolvable tension with the Federal Rules. The strictly procedural provisions of the Kansas statute should therefore not apply in federal court. When presented with this question, the U.S. District Court for the District of Kansas - and ultimately the Tenth Circuit - should accordingly adopt the reasoning from the Ninth Circuit's Metabolife and Center for Medical Progress cases and determine that the Kansas anti-SLAPP statute's timing and discovery-limiting provisions do not apply in federal diversity actions because they are purely procedural mechanisms. This result preserves the statute's integrity by allowing its key provisions to remain applicable while also avoiding an Erie conflict. In fact, this result best serves Erie's "twin aims" because the substantive provisions remain viable as a deterrent to forum shopping and promotes equal administration of the laws by ensuring that a defendant may invoke the full protection intended by the Kansas legislature.

\section{Implications of Adopting the Ninth Circuit's Approach}

Adopting the Ninth Circuit's approach would not result in a complete bar of motions brought under the Kansas anti-SLAPP statute in federal court. Federal courts have held, and will likely continue to hold, that various provisions of state anti-SLAPP statutes do not conflict with the Federal Rules, and therefore apply in federal diversity actions. ${ }^{268}$

For example, the Second Circuit addressed the applicability of various provisions of the Nevada anti-SLAPP statute in a similar fashion. ${ }^{269}$ The court stated that the provisions granting immunity from civil liability and the mandatory fee shifting seemed "unproblematic" because these provisions: "(1) would apply in state court had suit been filed there; (2) is substantive within the meaning of Erie, since it is consequential enough that enforcement in federal proceedings will serve to discourage forum shopping and avoid inequity; and (3) does not squarely conflict with a

268. See, e.g., Planned Parenthood Fed'n of Am., Inc. v. Ctr. for Med. Progress, 890 F.3d 828 (9th Cir. 2018), cert. denied, 139 S. Ct. 1446 (2019); Metabolife, 264 F.3d at 845; Adelson v. Harris, 774 F.3d 803, 809-10 (2d Cir. 2014).

269. See Adelson, 774 F.3d at 809-10 (citing NEv. Rev. StAT. ANN. $§ 41.635-.670$ (West, Westlaw through 2019 Reg. Sess.)). 
valid federal rule." ${ }^{270}$ However, the court suggested the discovery-barring provision may have presented a "closer question."271 The Second Circuit ultimately avoided having to resolve the question, though its discussion suggests that it would be willing to decline to apply antidiscovery provisions in state anti-SLAPP statutes. ${ }^{272}$

A few federal district courts have adopted the Ninth Circuit's approach. ${ }^{273}$ The U.S. District Court for the Eastern District of Michigan recently adopted the Ninth Circuit's reasoning, finding that the Ninth Circuit's "manner of harmonizing the Federal Rules and California's antiSLAPP statute is entirely sensible."274 The court agreed with the Ninth Circuit's decision in Center for Medical Progress that "if an anti-SLAPP motion challenges the 'legal sufficiency' of a claim, then a federal district court should apply Rule 12(b)(6) standards; and if the motion challenges the 'factual sufficiency' of the claim, then the court should apply Rule 56 standards (including opportunity for discovery)." ${ }^{, 75}$ This allows a court to look past all of the "procedural fencing" by finding a defendant "has essentially filed an early summary-judgment motion on a limited record." ${ }^{276}$ The court noted that the anti-SLAPP statutes merely "puts some extra skin in the game" because if the defendant wins its motion, it can recover attorney's fees and costs, but if the defendant files a frivolous motion, the plaintiff recovers fees. ${ }^{277}$

In the U.S. District Court for the District of Kansas, this would mean that the burden-shifting provision found in subsection (d) of the Kansas statute would continue to apply in federal diversity actions. The statute provides that a defendant bringing the special motion to strike has the initial burden of demonstrating that they were exercising their right of free speech, right to petition, or right of association. ${ }^{278}$ If the defendant meets

270. Id. at 809 (citing Liberty Synergistics, Inc. v. Microflo, Ltd., 718 F.3d 138, 153 (2d Cir. 2013)).

271. Id.

272. See id.

273. See, e.g., Vangheluwe v. Got News, LLC, 365 F. Supp. 3d 836, 843-44 (E.D. Mich. 2019); World Kitchen, LLC v. Am. Ceramic Soc'y, No. 12-cv-8626, 2013 WL 5346424, at*17-18 (N.D. Ill. Sep. 19, 2013) ("If a defendant makes an anti-SLAPP motion to strike founded on purely legal arguments, then the analysis is made under Fed. R. Civ. P. 8 and 12 standards; if it is a factual challenge, then the motion must be treated as though it were a motion for summary judgment and discovery must be permitted.' ... At this stage of the pleadings, a Rule 12 standard must be applied to Defendants' [anti-SLAPP] Motion." (quoting Z.F. v. Ripon Unified Sch. Dist., 428 F. App'x 239, 240 (9th Cir. 2012))).

274. Vangheluwe, 365 F. Supp. $3 \mathrm{~d}$ at 844.

275. Id. (quoting Planned Parenthood Fed'n of Am., Inc. v. Ctr. for Med. Progress, 890 F.3d 828, 834 (9th Cir. 2018), cert. denied, 139 S. Ct. 1446 (2019)).

276. $I d$.

277. Id. at $844-45$.

278. Kan. Stat. AnN. § 60-5320(d) (West 2016 \& Supp. 2019). 
its burden, the burden then shifts to the plaintiff "to establish a likelihood of prevailing on the claim by presenting substantial competent evidence to support a prima facie case." ${ }^{, 79}$ If the plaintiff can satisfy its burden, the defendant's motion will be denied. ${ }^{280}$

Similarly, the provision allowing recovering attorney's fees would remain applicable. The timing requirements found in subsection (d), ${ }^{281}$ however, would not apply in federal court, nor would the discoverylimiting provisions found in subsections (e)(1)-(2). ${ }^{282}$ This result does not pose a problem, because subsection $(\mathrm{k})$ provides that the statute "shall be applied and construed liberally to effectuate its general purposes," and that if a court finds any part of the statute inapplicable, the remaining provisions continue to apply. ${ }^{283}$ The statute's text therefore also supports adopting the Ninth Circuit's approach of circumscribing only select provisions while continuing to apply the substantive protections afforded to defendants.

\section{CONCLUSION}

The substantive provisions of the Kansas anti-SLAPP statute can be construed to work together with the Federal Rules of Civil Procedure. The Kansas anti-SLAPP statute is designed to guide the substantive standards that determine when First Amendment petitioning activity can receive heightened protections. The Kansas anti-SLAPP law must therefore be understood as supplementing - rather than supplanting - the Federal Rules. When presented with this question in the future, the U.S. District Court for the District of Kansas - and ultimately, the Tenth Circuitshould circumscribe only select portions of the anti-SLAPP statute in federal diversity actions, while continuing to apply the substantive provisions. This outcome best protects SLAPP defendants while also aligning with the purposes of the Erie doctrine. This result will serve both federal and state interests, discourage forum shopping, promote the equitable administration of the laws, and most importantly, provide

279. Id.

280. Id.

281. Id. ("The motion to strike made under this subsection may be filed within 60 days of the service of the most recent complaint or, in the court's discretion, at any later time upon terms it deems proper. A hearing shall be held on the motion not more than 30 days after the service of the motion.").

282. Id. $\S 60-5320(\mathrm{e})(1)-(2)$ ("On a motion by a party or on the court's own motion and on a showing of good cause, the court may allow specified and limited discovery relevant to the motion. Except as provided in subsection (e)(1), all discovery, motions or other pending hearings shall be stayed upon the filing of the motion to strike. The stay of discovery shall remain in effect until the entry of the order ruling on the motion except that the court, on motion and for good cause shown, may order that specified discovery, motions or other pending hearings be conducted.").

283. Id. $\S 60-5320(\mathrm{k})$. 
SLAPP defendants the full protection the Kansas legislature envisioned when drafting the Kansas anti-SLAPP statute. 